\title{
A Critical Assessment of Recent Work on the Application of Gas/Particle Partitioning Theories to Cigarette Smoke
}

by

\author{
J.H. Lauterbach \\ Brown \& Williamson Tobacco Corporation \\ P.O. Box 1056 \\ Macon, GA 31202-1056
}

\section{SUMMARY}

In the August 1997 issue of Environmental Science \& Technology (ES\&T), PANKOW and co-workers at the Oregon Graduate Institute reported that the addition of ammonia-containing additives to cigarette tobacco increased the amount of unprotonated nicotine in cigarette mainstream smoke (MSS) and thus increased the bioavailability of nicotine to the smoker. Articles about PANKOW's work also appeared in other publications along with allegations that ammonia-containing additives are used to manipulate nicotine deliveries. However, initial review of PANKOW's research and that reported on environmental tobacco smoke (ETS) in an earlier paper showed that potentially serious issues existed with PANKOW's experimental data and conclusions. Consequently, a critical assessment of PANKOW's research and the underlying theories of gas/particle partitioning was undertaken. This assessment confirmed that PANKOW and his co-workers made a number of errors not only in their determinations of the gas/particle partitioning coefficients for nicotine in MSS and ETS but also in the interpretations of the data. During the preparation of this assessment, data from other researchers became public. These data showed that there was no correlation between tobacco ammonia (including residual ammonia from the use of ammonia-containing additives) and MSS ammonia deliveries and MSS smoke $\mathrm{pH}$, and that the amount of unprotonated nicotine in the undiluted MSS of a full flavor (FF) American filter cigarette was less than $0.1 \%$.
These new data fully substantiated the findings of this assessment, and it can be safely concluded that the assertions made by PANKOW and his co-workers were incorrect. However, this assessment also showed that there is significant merit in the application of PANKOW's theory of absorptive partitioning for the estimation of the gas/particle partitioning of semivolatile components in MSS and ETS. Application of PANKOW's theory along with data from recent tobacco related conferences has allowed estimation of the gas/particle partition coefficient for nicotine in cigarette MSS and also has allowed approximation of values for the activity coefficient of nicotine in mainstream particulate matter. [Beitr. Tabakforsch Int. 19 (2000) 65-83]

\section{ZUSAMMENFASSUNG}

In der Ausgabe vom August 1997 der Zeitschrift Environmental Science \& Tecbnology (ES\&T) haben PANKOW und Mitarbeiter vom Oregon Graduate Institute berichtet, dass die Zugabe von ammoniumhaltigen Additiven zum Cigarettentabak den Gehalt an unprotoniertem Nikotin im Hauptstromrauch von Cigaretten (HSR) erhöht und somit die Bioverfügbarkeit des Nikotins für den Raucher ansteigt. Veröffentlichungen über PANKOWs Arbeit erschienen ebenfalls in anderen Zeitschriften zusammen mit Behauptungen, dass ammoniumhaltige Additive eingesetzt werden, um die Freisetzung von Nikotin zu manipulieren. Eine erste Überprüfung von PANKOWs 
Untersuchungen und eine frühere Untersuchung über Tabakrauch in der Raumluft (ETS) zeigten, dass gravierende Differenzen zwischen PANKOWs experimentellen Daten und seine Schlußfolgerungen existieren. Folglich wurde eine kritische Bewertung von PANKOWs Forschung und den zugrundeliegenden Theorien zur Verteilung der Komponenten des Cigarettenrauchs auf Gasund Partikelphase vorgenommen. Die vorliegende Bewertung bestätigte, dass PANKOW und Mitarbeiter eine Reihe von Fehlern machten, nicht nur bei ihrer Bestimmung der Verteilungskoeffizienten von Nikotin zwischen Gas- und Partikelphase im HSR und ETS, sondern auch bei ihrer Interpretation der Daten. Während der Ausarbeitung dieser Bewertung wurden Untersuchungsergebnisse von anderen Forschern bekannt. Diese Ergebnisse zeigten, dass es keinen Zusammenhang zwischen Ammonium im Tabak (einschließlich des Ammoniums aus ammoniumhaltigen Additiven) und der Freisetzung von Ammonium im HSR sowie des $\mathrm{pH}$ Wertes von HSR gab, und dass die Konzentration von unprotoniertem Nikotin im unverdünnten HSR einer US-amerikanischen Full-Flavour Filtercigarette weniger als $1 \%$ betrug. Diese neuen Daten bestätigten vollends die Ergebnisse der hier vorliegenden Beurteilung und es läßt sich mit Sicherheit die Schlußfolgerung ziehen, dass die Behauptungen von PANKOW und Mitarbeitern falsch waren. Die vorliegende Beurteilung zeigte jedoch auch, dass die Anwendung von PANKOWs Theorie der absorptiven Verteilung einen beträchtlichen Wert für die Abschätzung der Gasphasen/Partikelphasenverteilung semivolatiler Verbindungen im HSR und ETS besitzt. Die Anwendung von PANKOWs Theorie unter Berücksichtigung diesbezüglicher Forschungsergebnisse, die kürzlich auf Tabaktagungen präsentiert wurden, ermöglicht die Abschätzung der Verteilungskoeffizienten von Nikotin zwischen Gasphase und Partikelphase im HSR von Cigaretten und ermöglicht ebenfalls, Werte für den Aktivitätskoeffizienten von Nikotin in der Partikelphase des HSR abzuschätzen. [Beitr. Tabakforsch Int. 19 (2000) 65-83]

\section{RESUME}

Dans l'édition du mois d'août 1997 de la revue Environmental Science \& Technology (ES\&T), PANKOW et ses collaborateurs de l'Oregon Graduate Institute ont rapporté que l'apport d'additifs contenant de l'ammoniac au tabac de cigarettes augmente la teneur en nicotine non protonée dans le courant principal de la fumée de cigarettes (CP) et ainsi la biodisponibilité de la nicotine dans l'organisme du fumeur. Des réactions relatives à l'étude de PANKOW ont été publiées dans d'autres revues et prétendent que des additifs contenant de l'ammoniac sont employés pour manipuler le rendement en nicotine. Une première évaluation des résultats de PANKOW et une étude antérieure sur la fumée de tabac ambiante (FTA) ont révélé que des différences notables existaient entre les données expérimentales de PANKOW et ses déductions. On a donc entrepris une analyse critique des recherches de PANKOW et les théories sous-jacentes sur la répartition des composants entre la phase gazeuse et la phase particulaire. Cette évaluation a confirmé que PANKOW et collaborateurs ont commis plusieurs erreurs, non seulement dans la détermination des coefficients de répartition entre la phase gazeuse et la phase particulaire de la nicotine dans le CP et la FTA, mais aussi en ce qui concerne l'interprétation des données. Pendant la préparation de cette évaluation, les données d'autres études ont été publiées. Ces données ont révélé qu'il n'existait pas de corrélation entre l'ammoniac du tabac (y compris des résidus d'ammoniac après utilisation d'additifs contentant de l'ammoniac) et la teneur en ammoniac dans le CP et le $\mathrm{pH} \mathrm{du} \mathrm{CP}$, et que la teneur en nicotine non protonée dans le CP non dilué d'une cigarette américaine filtre plein arôme était inférieure à $0.1 \%$. Ces nouvelles données étaient en accord étroit avec les résultats de cette évaluation et on peut en toute sécurité en tirer la conclusion que les assertions faites par PANKOW et collaborateurs étaient fausses. Cependant, cette assertion a également montré que l'application de la théorie de la répartition absorptive développée par PANKOW a une valeur significative pour l'évaluation de la répartition des composants semi-volatils entre la phase gazeuse et la phase particulaire du CP et de la FTA. L'application de la théorie de PANKOW avec les données présentées lors de congrès récents relatifs au tabac a permis l'estimation du coefficient de répartition de la nicotine dans le CP de cigarette entre la phase gazeuse et la phase particulaire et a également permis l'approximation des valeurs relatives au coefficient d'activité de la nicotine dans la matière particulaire totale du CP. [Beitr. Tabakforsch Int. 19 (2000) 65- 83]

\section{INTRODUCTION}

Gas/particle partitioning processes in atmospheric aerosols have been studied extensively, and the theories developed to explain such processes have been recently reviewed by GOSS and SCHWARZENBACH (1). James F. PANKOW has been one of the leading scientists in that field, and he is particularly well known for his development of the theories for adsorptive and absorptive partitioning of atmospheric aerosols (2, 3, 4). Between 1994 and 1997, PANKOW and his co-workers (hereinafter collectively called PANKOW) extended their work on atmospheric aerosols to cigarette smoke aerosols. They published a series of papers on the partitioning of various substances between the gas phase and the particulate phase in both environmental tobacco smoke (ETS) and cigarette mainstream smoke (MSS) $(5,6,7,8)$. The last paper received attention in the popular press as well as the scientific press because it contained allegations that the tobacco industry was using ammonia to increase the bioavailability of nicotine in cigarette smoke $(9,10)$. 
However, an "Additions and Corrections" to that paper was published in 1999 (11), and the corrected data had much less impact than those in the original publication did.

One purpose of this assessment is to show the applicability of gas/particle partitioning theories to cigarette smoke. Another purpose is to discuss PANKOW's application of these theories in the context of the information that was available at the time the research was done and in terms of information that has become available since it was published. These theories will be described briefly before discussing them with respect to PANKOW's work on MSS and ETS.

\section{THEORIES ON GAS/PARTICLE PARTITIONING IN AEROSOLS}

\section{Adsorptive partitioning}

The first of these theories deals with adsorptive partitioning. In this model, the particulate phase of the aerosol is comprised of spherical particles with a thin layer of an organic phase surrounding an inert core such as found in urban particulate matter (UPM) (7). PANKOW provided the theoretical basis for adsorptive partitioning (2) and confirmed his theory with data from YAMASAKI's work on environmental aerosols (12). The work by YAMASAKI and by PANKOW lead to the definition and practical use of a gas/particle partitioning coefficient, $K_{\mathrm{p}}$, which is defined as follows for a given semivolatile component in an aerosol:

$$
K_{\mathrm{p}}=\frac{\frac{F}{\mathrm{TSP}}}{A}
$$

In Equation [1.1], $A$ and $F$ are the artifact-free equilibrium concentrations $\left(\mathrm{ng} / \mathrm{m}^{3}\right)$ of a given component in the gas phase and associated suspended particulate, respectively, at a given temperature and humidity. TSP $\left(\mu \mathrm{g} / \mathrm{m}^{3}\right)$ is the concentration of total suspended particulate matter in the aerosol. The quantity F/TSP is related to the thermodynamic activity of the component of interest on/in the particulate matter. PANKOW $(13,14)$ also showed for polycyclic aromatic hydrocarbons (PAHs) in several different environmental situations that:

$$
\log K_{\mathrm{p}}=m_{\mathrm{p}} / T+b_{\mathrm{p}}
$$

In Equation [1.2], $T$ is the temperature $\left({ }^{\circ} \mathrm{K}\right)$, and $m_{\mathrm{p}}$ and $b_{\mathrm{p}}$ are calculated according to Equations [1.3] and [1.4], respectively (2).

$$
\begin{aligned}
& m_{\mathrm{p}}=\frac{Q}{2.303 R}-\frac{T}{4.606} \\
& b_{\mathrm{p}}=\log \left(A_{\mathrm{tsp}} t_{0}\right) / 275(M / T)^{\frac{1}{2}}+0.2171
\end{aligned}
$$

In the above equations, $Q$ is the enthalpy of desorption from the surface for the component of interest, $R$ is the gas constant, $A_{\text {tsp }}\left(\mathrm{cm}^{2} / \mu \mathrm{g}\right)$ is the specific surface area of the aerosol, $t_{0}(\mathrm{sec})$ is a molecular vibration time, and $M$ is the molecular weight of the component of interest. PANKOW showed that plots of $\log K_{\mathrm{p}}$ versus $1 / T$ were approximately linear with a slope of $m_{\mathrm{p}}$. Also, for a given class of compounds, most members of the class had a common $y$-intercept. If the partitioning is purely due to physical adsorption, Equation [1.1] can also be expressed as:

$$
K_{\mathrm{p}}=\frac{N_{\mathrm{s}} A_{\text {tsp }} T \exp \left(\frac{Q_{1}-Q_{\mathrm{v}}}{R T}\right)}{1600 p_{\mathrm{L}}^{\mathrm{o}}}
$$

In Equation [1.5], $N_{\mathrm{s}}$ (moles of sorption sites per $\mathrm{cm}^{-2}$ of the aerosol), $Q_{1}\left(\mathrm{~kJ} \mathrm{~mol}^{-1}\right)$ is the enthalpy of desorption from the surface, $Q_{\mathrm{v}}$ is the enthalpy of vaporization for the components of interest, and $p_{\mathrm{L}}{ }^{\circ}$ is its vapor pressure.

\section{Absorptive partitioning}

PANKOW also dealt with the situation where the gas/particle partitioning is absorptive in nature or is a mixture of absorptive and adsorptive processes $(3,4)$. In cases where the partitioning is dominated by absorptive processes, PANKOW stated that for a given component, $i$ :

$$
K_{\mathrm{p}, \mathrm{i}}=\frac{f_{\mathrm{om}} 760 R T}{10^{6} \mathrm{MW}_{\mathrm{om}} \gamma_{\mathrm{i}} p_{\mathrm{L}, \mathrm{i}}^{\mathrm{o}}}
$$

In Equation [1.6], $f_{\text {om }}$ is the fraction of organic matter in the particulate phase, $R$ is the gas constant $\left(8.2 \times 10^{-5} \mathrm{~m}^{3}\right.$ atm $\left.\mathrm{mol}^{-1} \mathrm{~K}^{-1}\right), T$ is the temperature $\left({ }^{\circ} \mathrm{K}\right), \mathrm{MW}_{\text {om }}$ is the number-average molecular weight of the particulate phase, $\gamma_{\mathrm{i}}$ is the activity coefficient of the given component in the particulate phase, and $p_{\mathrm{L}, \mathrm{i}}^{\circ}$ is the vapor pressure of pure compound, $i$, at temperature, T. PANKOW also expressed Equation [1.6] in logarithmic format as:

$$
\log K_{\mathrm{p}, \mathrm{i}}=-\log p_{\mathrm{L}, \mathrm{i}}^{\mathrm{o}}+\log \frac{f_{\mathrm{om}} 760 R T}{10^{6} \mathrm{MW}_{\mathrm{om}} \gamma_{\mathrm{i}}}
$$

Equation [1.7] could also be reduced to $(5,7)$ :

$$
\log K_{\mathrm{p}, \mathrm{i}}=m_{\mathrm{r}} \log p_{\mathrm{L}, \mathrm{i}}^{\mathrm{o}}+b_{\mathrm{r}}
$$

According to PANKOW, plots of $\log K_{\mathrm{p}}$ versus $\log p_{\mathrm{L}}^{\mathrm{o}}$ will tend to have a slope of approximately -1 when $1 / \gamma$ remains constant within the compound class of interest. PANKOW also reported that the second term of Equation [1.7], $\log \left(f_{\text {om }} 760 R T / 10^{6} \mathrm{MW}_{\text {om }} \gamma_{\mathrm{i}}\right)$, had values from -8.9 to -7.3 (3). It is important to note that Equations [1.6] to [1.8] show that the ratio of the amount of compound in the gas phase to the amount present in the particulate phase is independent of the total amount of the compound present. 


\section{Application of gas/particle partitioning theory to cigarette smoke and related aerosols}

While PANKOW's early work on aerosols was related to UPM, his work has been extended by others to include aerosols such as wood smoke that are more similar to cigarette smoke. In particular, three papers from KAMENS's group at University of North Carolina are relevant to the application of PANKOW's theories to cigarette smoke $(15,16,17)$. Those three papers outline two somewhat different approaches to predicting the gas/particle partitioning for a given component of an aerosol where absorptive partitioning is the predominant process as in the case of cigarette smoke (7). Furthermore, they cast doubt on PANKOW's use of unit activity coefficients when the semivolatile materials have different polarities and functional groups, the effects of water in the particulate matter on $K_{\mathrm{p}}$ (which, in turn, raises questions about the validity of Equation [1.8]), and the extent to which equilibrium is obtained in freshly generated aerosols, a point which PANKOW had conceded earlier (18). Also, PANKOW recently advocated the use of the octanol/air partition coefficient as a correlating parameter for gas/particle partitioning coefficients for systems where absorptive partitioning is the dominant process (19).

While PANKOW's work has been fairly recent, the topic of gas/particle partitioning is not new as far as cigarette smoke is concerned. In 1966, VEKRIS and HOOK of BAT presented the results of their studies on gas/particle partitioning (20). One of the key findings from their work was that for a given compound in a given type of smoke, the ratio of compound between the two phases was independent of the total amount of the compound present in smoke. This finding applied not only to neutral compounds such as aldehydes and ketones, but also to pyridine bases. In addition, they found that for compounds of the same chemical type in the same smoke, the ratio (amount in gas phase to amount in particulate phase) increased as the vapor pressure increased. Also, they concluded that there was a dynamic equilibrium between the two phases of smoke.

\section{DISCUSSION}

\section{Environmental tobacco smoke}

It is important to understand PANKOW's work on ETS before considering his work on MSS. This is because PANKOW first applied his models and methods to ETS and because he used data from his ETS experiments to help justify his conclusions on MSS. PANKOw's first research related to smoke chemistry was his paper on gas/particle partitioning of PAHs and alkanes in ETS (5). According to PANKOW, one of the objectives of the research was to determine if the values for $K_{\mathrm{p}}$ that were determined for those compounds in environmental aerosols could be extended to the partitioning of those compounds in ETS, which indeed was the case.

PANKOW's ETS samples came from an indoor recreational area that permitted smoking. His sampling system consisted of a glass-fiber filter (GFF) to collect the particulate phase followed by polyurethane foam (PUF) plugs to collect the gas-phase PAHs and Tenax-GC traps to collect the more volatile compounds in the gas phase. The compounds on the filters and PUF plugs were Soxhlet-extracted and analyzed by GC/MS while those on the Tenax-GC were analyzed by thermal desorption GC/MS. Those analytical measurements along with the weight of the particulate matter trapped on the GFF and the volume of air sampled permitted calculation of values for $K_{\mathrm{p}}$. PANKOW claimed a slope of -1 for the plot of log $K_{\mathrm{p}}$ versus $\log p_{\mathrm{L}}^{\circ}$ for a series of PAHs (chrysene, pyrene, fluoranthene, anthracene, phenanthrene, and fluorene) as well as a series of $n$-alkanes $\left(\mathrm{C}_{16}-\mathrm{C}_{22}\right)$ in his ETS samples. He also claimed that PAHs were more tightly bound to the particulate matter in ETS than to that in UPM. However, inspection of PANKOW's data indicated that there was likely a problem with his collection and/or analysis on the most volatile members of each series. The data points for those compounds fell below the respective regression lines.

PANKOW's next research was first presented in 1996 (6) published shortly thereafter (7). The analytes investigated included not only those of the previous work but also quinoline, isoquinoline, nicotine, and carbazole. One of the conclusions presented in both papers was that the nitrogen compounds studied were more tightly bound to the particulate phase of ETS than were the PAHs and alkanes. PANKOw based this conclusion on the fact that when plots of $\log K_{\mathrm{p}}$ versus $\log p_{\mathrm{L}}^{\circ}$ were made for each class of compounds, the values for the $\mathrm{N}$-containing compounds were more positive than those for the PAHs and alkanes whose vapor pressures were similar. PANKOW ascribed this finding to the presence of acidic compounds in the particulate phase of ETS. The data in the two documents differed in some cases with the most noticeable difference being in the values for the vapor pressure for carbazole. The former gave a value for $\log p_{\mathrm{L}}^{0}$ of -2.96 at $20^{\circ} \mathrm{C}\left(1.1 \times 10^{-3}\right.$ torr $)$ while the latter gave a value for $\log p_{\mathrm{L}}^{\mathrm{o}}$ of -4.82 at $20^{\circ} \mathrm{C}\left(1.5 \times 10^{-5}\right.$ torr). PANKOW was able to use the former value for a satisfactory regression of $\log K_{\mathrm{p}}$ versus $\log p_{\mathrm{L}}^{\circ}$ for the $\mathrm{N}$-containing compounds, but was unable to do so when the latter value was used. Indeed, he stated that the latter value was probably too low, but estimation of the vapor pressure at $20^{\circ} \mathrm{C}$ for carbazole using a modification of the Watson correlation (21) gave a value for $\log p_{\mathrm{L}}^{\circ}$ of approximately -7.4 .

In addition, the analytical method for determining $A$ and $F\left[\right.$ the artifact-free equilibrium concentrations $\left(\mathrm{ng} / \mathrm{m}^{3}\right)$ of a given component in the gas phase and associated suspended particulate, respectively] was changed to a desorption method employing what PANKOW called his fractional approach to equilibrium (18); and the GFF was 
replaced by a quartz fiber filter (QFF).

For the determination of $K_{\mathrm{p}}$ by PANKOW's desorption method (fractional approach to equilibrium), the particulate matter was collected on a filter [GFF, TMF (Teflon ${ }^{\mathrm{TM}}$ membrane filter), or QFF]; and the net weight of particulate matter $\left(M_{\mathrm{p}}\right)$ was determined. Then a section of the filter was extracted, and the analytes of interest determined. This gave a value for each analyte, $M_{\mathrm{e}}$. Additional sections of the filter were taken and these were desorbed at ambient temperatures with humidified nitrogen for know periods of time. The desorbed analytes were collected on Tenax-TA traps, and these traps were analyzed by thermal-desorption GC/MS. This gave values for each analyte at each time period, $M_{\mathrm{t}}$. When the quantity $M_{\mathrm{t}} / M_{\mathrm{e}}$ was plotted versus volume $\left(\mathrm{m}^{3}\right)$ of gas used for desorption, the slope of the line was $1 / K_{\mathrm{p}} M_{\mathrm{p}}$ (from Equation [1.1]). For volatile compounds, $K_{\mathrm{p}}$ was relatively small, and the slope of the $1 / K_{\mathrm{p}} M_{\mathrm{p}}$ line was much greater for the initial sampling times than it was for the later ones. PANKOW determined the slope by nonlinear regression analysis. It must be pointed out that these desorption experiments were done over a period of days, and the first data points appear to have been taken after tens of liters of desorption gas had passed through the filter.

Since the early data points have more of an effect on the slope than the later ones, and since the early data points are much more important for the more volatile compounds, the usefulness of this fractional approach to equilibrium may be limited. The full experimental details of PANKOW's research on ETS using the fractional approach to equilibrium are given in a dissertation by one of PANKOW's students (22).

PANKOW (7) had problems explaining the data from his ETS studies, which are summarized in Table 1. This Table shows the data from the experiments performed at $20^{\circ} \mathrm{C}(6,7)$ as well as those performed at $25^{\circ} \mathrm{C}(5)$. The column in Table 1 marked "Corr. to $25^{\circ} \mathrm{C}$ " contains the values of $K_{\mathrm{p}}$ measured at $20^{\circ} \mathrm{C}$ corrected to $25^{\circ} \mathrm{C}$ for both changes in temperature and changes in vapor pressure according to Reference 4. If both of PANKOW's methods for determining $K_{\mathrm{p}}$ were equivalent, the values of $K_{\mathrm{p}}$ determined experimentally at $20^{\circ} \mathrm{C}$, but corrected to $25{ }^{\circ} \mathrm{C}$ should be equivalent to those determined experimentally at $25^{\circ} \mathrm{C}$. In many cases, they were not. As PANKOW noted, he had problems with the data from his most volatile alkane, hexadecane. His value of $\log K_{\mathrm{p}}$ of -3.96 for a $\log p_{\mathrm{L}}^{0}$ of -3.17 is too high. If PANKOW's regression data were used, $\log K_{\mathrm{p}}$ should have been more on the order of -4.6 . His error appeared to come from his measurement system as correcting his earlier data for temperature by Equation [1.6] gives a value of -4.68 . While this error and the differences in the temperature-corrected $K_{\mathrm{p}}$ values may seem trivial, it is important when PANKOW's data for nicotine in ETS are considered. As shown in Table 1, PANKOw found a value for $\log K_{\mathrm{p}}$ for nicotine in ETS at $20^{\circ} \mathrm{C}$ of $-2.83 . K_{\mathrm{p}}$ was 0.001479 (antilog of -2.83) and TSP was reported to be
$454.8 \mu \mathrm{g} / \mathrm{m}^{3}$. Substitution of these values in Equation [1.1] gives a ratio of $F / A$ of 0.673 . Data on $F / A$ from a well known collaborative study of nicotine in ETS (23) gave values of $F / A$ of about 0.03 for TSPs ranging from $184 \mu \mathrm{g} / \mathrm{m}^{3}$ to $990 \mu \mathrm{g} / \mathrm{m}^{3}$. In the paper under discussion, PANKOW speculated that the magnitude of his value of $K_{\mathrm{p}}$ for nicotine could be explained by the fact that nicotine in ETS could be monoprotonated as in MSS. He did not note there were several reports in the literature at that time that indicated that over $95 \%$ of the nicotine in ETS is in the gas phase $(23,24,25,26,27)$, and that values for $\log K_{\mathrm{p}}$ calculated from the data of CAKA et al. (23) were much smaller than he found.

A review of PANKOW's experimental procedure indicated that two errors were made. First, he did not take the normal precautions to prevent losses when working with trace levels of nicotine $(28,29,30)$. Second, he failed to heed the warnings of others about using particulate filters alone or gas sampling devices behind filters to determine gas-phase concentrations $(23,31,32,33,34)$. The warnings, which were based on experimental data, showed that GFFs would absorb gas-phase nicotine. While PANKOW claimed that his approach eliminated artifacts caused by other types of sampling systems, it appears that it did not work reliably for nicotine in ETS. Indeed, nicotine was not included in the plot of $M_{\mathrm{t}} / M_{\mathrm{e}}$ versus $V$ for the other analytes discussed in that paper. Also in that paper, PANKOW commented on the fact that detailed microscopic examination of the QFF used to sample ETS did not reveal the presence of discrete particles, but that the fibers were wetted with a liquid-like material. From that finding, PANKOW concluded that absorptive partitioning was the predominate process affecting gas/particle equilibrium in ETS, and he invoked Equation [1.6] to help explain his findings for the alkanes and PAHs. PANKOW assumed that $f_{\text {om }}$ was 1.00 and that $\mathrm{MW}_{\text {om }}$ was 85 . If he had done this calculation for nicotine and used the value of 0.033 torr for $p_{\mathrm{L}}^{\circ}$ (vapor pressure of nicotine at $20^{\circ} \mathrm{C}$ ) given in that paper, and assumed an activity coefficient of unity, he would have obtained $\log K_{\mathrm{p}}$ of approximately -5.1 and a $P_{\mathrm{g}}(\%)$ of 99.6. Even if he had assumed an activity coefficient for nicotine of 0.08 (35), his calculations would have given $\log K_{\mathrm{p}}$ of approximately -4.0 and a $P_{\mathrm{g}}(\%)$ of 95.5 . This is a key point. First, it shows that PANKOW's equation for absorptive partitioning gives a good approximation of the amount of gas-phase nicotine in ETS. More importantly, it shows that PANKOw's experimental approach gave an incorrect value.

PANKOW then described the effects of acid-base equilibria on gas/particle partitioning. First he defined $\varphi$ as the fraction of a compound that is in the particulate phase.

$$
\varphi=\frac{F}{F+A}=\frac{K_{\mathrm{p}} \mathrm{TSP}}{1+K_{\mathrm{p}} \mathrm{TSP}}
$$

The fraction in the gas phase is then $1-\varphi$. He then defined $\alpha_{\mathrm{fb}}$ as the fraction of particulate-phase nicotine in 
Table 1.

Summary of data from PANKow's ETS experiment $(6,7)$

\begin{tabular}{|c|c|c|c|c|c|}
\hline \multicolumn{3}{|c|}{ Measured at $20^{\circ} \mathrm{C}$ and $60 \% \mathrm{RH}$} & \multirow{2}{*}{$\begin{array}{c}\text { Corrected }^{\mathrm{a}} \text { to } 25^{\circ} \mathrm{C} \\
\log K_{\mathrm{p}}\left(\mathrm{m}^{3} / \mu \mathrm{g}\right)\end{array}$} & \multicolumn{2}{|c|}{ Measured at $25^{\circ} \mathrm{C}$ and $60 \% \mathrm{Rl}$} \\
\hline Compounds & $\log p_{L}^{\circ}$ (torr) & $\log K_{\mathrm{p}}\left(\mathrm{m}^{3} / \mathrm{\mu g}\right)$ & & $\log p_{L}^{\circ}$ (torr) & $\log K_{\mathrm{p}}\left(\mathrm{m}^{3} / \mu \mathrm{g}\right)$ \\
\hline \multicolumn{6}{|l|}{ n-Alkanes } \\
\hline $\mathrm{C}_{16}$ & -3.17 & -3.96 & -4.22 & -2.91 & -4.93 \\
\hline $\mathrm{C}_{17}$ & -3.70 & -3.98 & -4.25 & -3.43 & -4.35 \\
\hline $\mathrm{C}_{18}$ & -4.23 & -3.71 & -4.00 & -3.94 & -3.95 \\
\hline $\mathrm{C}_{19}$ & -4.76 & -3.36 & -3.67 & -4.45 & -3.49 \\
\hline $\mathrm{C}_{20}$ & -5.28 & -2.76 & -3.08 & -4.96 & -3.01 \\
\hline $\mathrm{C}_{21}$ & -5.81 & -2.33 & -2.66 & -5.48 & -2.52 \\
\hline $\mathrm{C}_{22}$ & -6.34 & -1.65 & -2.00 & -5.99 & -2.24 \\
\hline \multicolumn{6}{|l|}{ PAHs } \\
\hline Fluorene & -2.42 & -4.64 & -4.83 & -2.23 & -5.09 \\
\hline Phenanthrene & -3.23 & -3.18 & -3.39 & -3.02 & -3.66 \\
\hline Fluoranthene & -4.42 & -2.24 & -2.47 & -4.19 & -2.76 \\
\hline Pyrene & -4.61 & -2.16 & -2.40 & -4.37 & -2.59 \\
\hline Chrysene & -5.90 & -0.66 & -0.92 & -5.64 & -1.55 \\
\hline \multicolumn{6}{|l|}{$\mathrm{N}$-Containing } \\
\hline Quinoline & -1.25 & -4.16 & & $N R^{b}$ & NR \\
\hline Isoquinoline & -1.38 & -3.88 & & NR & NR \\
\hline Nicotine & -1.48 & -2.83 & & NR & NR \\
\hline Carbazole & -4.82 & -2.26 & & NR & NR \\
\hline
\end{tabular}

a Values determined at $20^{\circ} \mathrm{C}$ corrected to $25^{\circ} \mathrm{C}$ according to PANKOW (4)

${ }^{\mathrm{b}} \mathrm{NR}=$ Data not reported

the unprotonated form and that the concentration of unprotonated nicotine in the particulate phase was $\alpha_{\mathrm{fb}} F$ $\left(\mathrm{ng} / \mathrm{m}^{3}\right)$. Then, PANKOW said that the gas/particle partitioning coefficient for the unprotonated nicotine could be found by substituting $\alpha_{\mathrm{fb}} F$ in Equation [1.1] to give Equation [2.2]. Rearrangement of the terms gives Equation [2.3].

$$
\begin{aligned}
& K_{\mathrm{p}, \mathrm{fb}}=\frac{\frac{\alpha_{\mathrm{fb}} F}{\mathrm{TSP}}}{A}=\alpha_{\mathrm{fb}} K_{\mathrm{p}} \\
& K_{\mathrm{p}}=\frac{K_{\mathrm{p}, \mathrm{fb}}}{\alpha_{\mathrm{fb}}}
\end{aligned}
$$

PANKOW then said that when $\alpha_{\mathrm{fb}}$ « 1 (acidic smoke), the protonation of nicotine enhances its ability to partition to the ETS phase. However, that statement does not make sense given the sidestream and mainstream data on bright, Burley, and Oriental tobaccos that were reported by SAKUMA and co-workers $(36,37,38)$ and the $\mathrm{pH}$ data that were generated by BRUNNEMANN and HOFFMANN on MSS and sidestream smoke (SSS) from different types of commercial products (39). These studies showed that among very different types of tobacco, there was little difference in the SSS/MSS ratio for nicotine and the other smoke bases, and that there was little difference in the SSS smoke $\mathrm{pH}$ values. While ETS is a combination of both SSS and exhaled MSS, there appears to be nothing in the literature to indicate how protonation of the nicotine in tobacco or MSS could drive more nicotine into SSS and hence into ETS. Indeed, one report showed that the addition of acid to the tobacco column increased mainstream deliveries of nicotine (40) and thus decreased those in SSS.

\section{Effects of ammonia-releasing tobacco additives}

PANKOW also claimed that Equation [2.3] explained how addition of ammonia-releasing chemicals to tobacco would reduce the $K_{\mathrm{p}}$ for nicotine in MSS. He claimed that adding a base such as ammonia to the MSS will cause $\alpha_{\mathrm{fb}}$ to approach unity thus increasing the value of $1-\varphi$. However, as will be shown in the next part of the discussion, this does not happen.

In his most recent and most notable paper on tobacco smoke, PANKOW (8) described how he repeated his ETS measurements (this time with TMFs instead of GFFs or QFFs); and how he applied similar methodology to MSS from two commercial blended cigarettes, which he designated A and B (now known to have been Marlboro King Size (KS)and Camel KS, respectively). In both the ETS and MSS experiments, PANKOW performed his de- 
sorption experiments not only with humidified nitrogen as he had done previously $(6,7)$, but also with varying levels of ammonia added to the desorption gas to simulate the effect of added ammonia, which PANKOW alleged came from ammonia-releasing tobacco additives (8). PANKOW based his work on information published by the U.S. Food and Drug Administration, which also contained information taken from various documents from British American Tobacco Company and Brown \& Williamson Tobacco Corporation (41). It will be shown in the remainder of this discussion that PANKOW's experimental work and the conclusions that he obtained from them were flawed. However, as gas/particle partitioning does occur in MSS, SSS, and ETS, it is important to understand PANKOW's logic and the errors in his experimental work.

\section{Application of gas/particle partitioning theory to nicotine in smoke}

In order to adopt the gas/particle partitioning theory to nicotine, PANKOW had to redefine several terms. From acid-base theory PANKOW defined $\alpha_{\mathrm{fb}}$, the fraction of nicotine in smoke that is not protonated as shown in Equation [2.4].

$$
\alpha_{\mathrm{fb}}=\frac{1}{1+10^{-\mathrm{pH}} / 10^{-\mathrm{p} K_{2}}+10^{-2 \mathrm{pH}} / 10^{-\left(\mathrm{p} K_{1}+\mathrm{p} K_{2}\right)}}
$$

where $\mathrm{p} K_{1}$ is defined to be 3.12 at $20{ }^{\circ} \mathrm{C}$ and $\mathrm{p} K_{2}$ is defined to be 8.02 at $20^{\circ} \mathrm{C}$. Since $\mathrm{pH}$ values of less than 4 are not expected in MSS, PANKOW simplified Equation [2.4] to Equation [2.5].

$$
\alpha_{\mathrm{fb}}=\frac{1}{1+10^{-\mathrm{pH}} / 10^{-\mathrm{p} K_{2}}}
$$

When MSS pH (method not defined) $<\mathrm{p} K_{2}$, then $\alpha_{\mathrm{fb}}<$ 1.0, but PANKOw said that when MSS pH approaches 8, $\alpha_{\mathrm{fb}}$ will approach unity assuming no smoke-phase activity corrections are required for any of the nicotine species involved. PANKOW then redefined $K_{\mathrm{p}}$ starting from the concept of $K_{\mathrm{p}, \mathrm{fb}}$ as defined by LIANG and PANKOW (7).

$$
K_{\mathrm{p}, \mathrm{fb}}=\frac{c_{\mathrm{p}, \mathrm{fb}}}{c_{\mathrm{g}}}
$$

In Equation [2.6], $c_{\mathrm{p}, \mathrm{fb}}(\mathrm{ng} / \mu \mathrm{g})$ is the concentration of unprotonated nicotine in the particulate phase, and $c_{\mathrm{g}}$ $\left(\mathrm{ng} / \mathrm{m}^{3}\right)$ is the concentration of nicotine (assumed to be all unprotonated) in the gas phase. The total nicotine in the particulate phase is defined as $c_{\mathrm{p}}(\mathrm{ng} / \mu \mathrm{g})$ and according to PANKOW, the following relationships hold.

$$
K_{\mathrm{p}, \mathrm{fb}}=\frac{\alpha_{\mathrm{fb}} c_{\mathrm{p}}}{c_{\mathrm{g}}}
$$

$$
K_{\mathrm{p}}=\frac{c_{\mathrm{p}}}{c_{\mathrm{g}}}=\frac{K_{\mathrm{p}, \mathrm{fb}}}{\alpha_{\mathrm{fb}}}
$$

PANKOW stated that at a given temperature and humidity, $K_{\mathrm{p}, \mathrm{fb}}$ was expected to be independent of the cigarette blend used, and in the absence of specific information on $\alpha_{\mathrm{fb}}$, Equation [2.8] could be used. PANKOW further stated that while he expected $K_{\mathrm{p}, \mathrm{fb}}$ to be independent of blend, he expected $K_{\mathrm{p}}$ to be dependent on blend and the mixture of acids and bases in the resulting pyrolysis products. Currently, there is insufficient evidence to decide if PANKOW's hypothesis with regard to $K_{\mathrm{p}, \mathrm{fb}}$ is correct. It will be shown later on in this discussion that PANKOW's hypothesis with regard to $K_{\mathrm{p}}$ in MSS is plausible; however, with the information at hand, it is difficult to differentiate changes in $K_{\mathrm{p}}$ as a result of dilution of the smoke and changes in $K_{\mathrm{p}}$ due to changes in the composition of the smoke aerosol. Therefore, it may be the case that smoke aerosols can be better described by PANKOW's own theory of absorptive partitioning (3) as represented by Equation [1.6] or as modified using the approaches described by KAMENS et al. $(15,16,17)$.

PANKOW used two additional equations to convert $K_{\mathrm{p}}$ values for nicotine in smoke into percent nicotine in the gas phase, $P_{\mathrm{g}}(\%)$.

$$
\begin{aligned}
& P_{\mathrm{g}}(\%)=\frac{c_{\mathrm{p}}}{c_{\mathrm{g}}}=100 \% \frac{c_{\mathrm{g}}}{c_{\mathrm{g}}+c_{\mathrm{p}} \mathrm{TSP}} \\
& P_{\mathrm{g}, \mathrm{eq}}(\%)=100 \% \frac{1}{1+K_{\mathrm{p}} \mathrm{TSP}}
\end{aligned}
$$

In Equation [2.10], it is assumed that there is gas/particle equilibrium; and this assumption will be used when Equation [2.10] is used for calculations related to ETS and MSS. Also, when Equations [2.9] and [2.10] are applied to MSS, TSP is equivalent to TPM expressed on a weight/volume basis $\left(\mu \mathrm{g} / \mathrm{m}^{3}\right)$. As will be discussed later, these equations are important to PANKOW's assertions about the amount of gas-phase nicotine that is available to a smoker.

The results from PANKOW's experimental work are shown in Table 2. These are taken from Table 1 of Reference 8. In addition, the levels of ammonia in the desorption gas have been converted to a per cigarette basis (MSS) or per filter basis (ETS) based on PANKOW's statement that a minimum of $40 \mathrm{~L}$ of desorption gas was used for each desorption experiment at a flow rate of about $1.5 \mathrm{~L} /$ minute [in his Additions and Corrections (11), PANKOW stated that the minimum amount of desorption gas used for the MSS experiments was $73 \mathrm{~L}$ ]. Reported MSS deliveries [15 puffs, $30-\mathrm{mL}$ puff volume, 2-sec puff duration, 30-sec puff interval, $35.5 \mathrm{~mm}$ diameter TMF (2- $\mu \mathrm{m}$ pore size) used instead of Cambridge filter pad] were approximately $10 \mathrm{mg} /$ cigarette TPM and $0.55 \mathrm{mg} /$ cigarette nicotine. For the ETS experiments, reported values were TSP, $420 \mu \mathrm{g} / \mathrm{m}^{3}$; filter load, 287 $\mu \mathrm{g} / \mathrm{cm}^{2}, c_{\mathrm{p}}$ for nicotine, $16 \mathrm{ng} / \mu \mathrm{g}$; area of desorbed filters, 
Table 2.

Summary of data from Pankow's ETS and MSS experiments (8)

\begin{tabular}{|c|c|c|c|}
\hline$p_{\mathrm{NH} 3} \times 10^{6}(\mathrm{~atm})$ at $20^{\circ} \mathrm{C}$ & $\mathrm{NH}_{3}$ used $(\mu \mathrm{g} /$ filter $)$ & $\mathrm{RH}(\%)$ & $\log K_{\mathrm{p}}$ \\
\hline \multicolumn{4}{|c|}{ ETS } \\
\hline \multicolumn{3}{|c|}{ Baseline value from LIANG and PANKOW (7) } & -2.83 \\
\hline 0.01 & 0.28 & 60 & -3.0 \\
\hline 1.7 & 48 & 60 & -3.72 \\
\hline 3.0 & 85 & 60 & -3.77 \\
\hline 21 & 594 & 60 & -4.38 \\
\hline 127 & 3590 & 60 & -4.93 \\
\hline \multicolumn{4}{|c|}{ MSS-A } \\
\hline 0.0 & 0 & 60 & -4.43 \\
\hline 1.04 & 29 & 60 & -4.4 \\
\hline 18.6 & 526 & 60 & -4.7 \\
\hline 80.4 & 2273 & 60 & -4.8 \\
\hline 185 & 5229 & 60 & -4.95 \\
\hline 196 & 5540 & 60 & -4.90 \\
\hline 427 & 12070 & 90 & -4.99 \\
\hline \multicolumn{4}{|c|}{ MSS-B } \\
\hline 140 & 3957 & 60 & -5.02 \\
\hline 296 & 8367 & 90 & -4.94 \\
\hline
\end{tabular}

$17.35 \mathrm{~cm}^{2}$; filter load on desorbed filters, $4979 \mu \mathrm{g}$. Reported temperature for the desorption experiments was $20^{\circ} \mathrm{C}$.

PANKOW's ETS experiments will be considered first. At a negligible ammonia level in the desorption gas (0.01 ppmV), PANKOw found $\log K_{\mathrm{p}}$ to be -3.0. However, if it is assumed that $95 \%$ of the nicotine was in the gas phase at the time the ETS was sampled and that the TSP level of $420 \mu \mathrm{g} / \mathrm{m}^{3}$ was measured accurately, then by Equation [2.10], $\log K_{\mathrm{p}}$ should have been -3.9. To get to a $\log K_{\mathrm{p}}$ approaching -3.9 , PANKOw had to use at a minimum $84 \mu \mathrm{g}(5 \mu \mathrm{mol})$ of ammonia for about $80 \mu \mathrm{g}$ $(0.5 \mu \mathrm{mol})$ of nicotine. If it is assumed that $97 \%$ (a value taken from Reference 23) of the nicotine was in the gas phase at the time the ETS was sampled, log $K_{\mathrm{p}}$ should have been -4.13 . To reach that level, PANKOw had to use a minimum of $594 \mu \mathrm{g}(35 \mu \mathrm{mol})$ of ammonia for about $80 \mu \mathrm{g}(0.5 \mu \mathrm{mol})$ of nicotine. These simple calculations with PANKOW's formulae and data show that either his experimental approach was incorrect or errors were made in the nicotine determinations needed for the calculation of the values of $\log K_{\mathrm{p}}$. The latter case appears to be the more plausible as PANKOW reported that his recoveries of the nicotine- $d_{3}$ surrogate internal standard ranged between $35 \%$ and $60 \%$.

If a similar tack is taken for PANKOW's MSS experiments, recently presented data and simple calculations show problems with his experimental approach. In 1998, JOSEPH and COCHRAN (42) reported that when MSS from a nonventilated US-blend filter cigarette was diluted (each puff diluted $35 \mathrm{~mL}$ to $400 \mathrm{~mL}$ ) exit the cigarette and put through a denuder, $0.96 \%\left[P_{\mathrm{g}}(\%)\right]$ of the nicotine in the diluted smoke was in the gas phase. Based on the reported puff count of 8 and an assumed TPM of 21.8 $\mathrm{mg} /$ cigarette, the TSP through the denuder was about $6.813 \times 10^{6} \mu \mathrm{g} / \mathrm{m}^{3}$. When these data were used with Equation [2.10], $\log K_{\mathrm{p}}$ was $-4.82\left(K_{\mathrm{p}}=1.51 \times 10^{-5}\right.$ $\left.\mathrm{m}^{3} / \mu \mathrm{g}\right)$. In a subsequent presentation, JOSEPH and COCHRAN (43) reported that a replication of their previous research yielded a $P_{\mathrm{g}}(\%)$ of $0.81 \pm 0.22 \%$. JOSEPH and COCHRAN also reported that they had improved their technique such that each puff had to be diluted to only $60 \mathrm{~mL}$ prior to the denuder. Their new findings showed a value of $0.014 \pm 0.010 \%$ for $P_{g}(\%)$ for a full flavor cigarette. In the same presentation, JOSEPH and COCHRAN also reported that when the same type of cigarette was made with $20 \%$ filter ventilation, $P_{\mathrm{g}}(\%)$ increased to $0.051 \pm 0.037 \%$. These data are summarized in Table 3. Calculated values for $\log K_{\mathrm{p}}$ from both studies by JOSEPH and COCHRAN ranged from -4.85 to -3.26 . KINSER et al. (44) presented data on the amount of nicotine that passed through the Cambridge pad and was trapped on XAD-4 resin during FTC (Federal Trade Commission) smoking. If it is assumed that nicotine passing through the Cambridge pad is gas-phase nicotine, levels for $P_{\mathrm{g}}(\%)$ and estimations of $\log K_{\mathrm{p}}$ can be obtained from KINSER's data by use of Equation [2.10] and data on the TPM deliveries and puff count. The results of these calculations and estimations also are shown in Table 3. Values for $P_{\mathrm{g}}(\%)$ ranged from $0.75 \%$ for a highly venti- 
Table 3.

Summary of calculated values of $K_{p}$ for nicotine in MSS $(42,43,44)$

\begin{tabular}{|c|c|c|c|c|}
\hline Cigarette & Per puff dilution & $P_{g}(\%)$ & $K_{\mathrm{p}}\left(\mathrm{m}^{3} / \mathrm{ug}\right)$ & $\log K_{\mathrm{p}}$ \\
\hline FFa American blend & $35 \rightarrow 400$ & 0.96 & $1.51 \times 10^{-5}$ & -4.82 \\
\hline FF American blend $(+E E)^{b}$ & $35 \rightarrow 400$ & 1.03 & $1.41 \times 10^{-5}$ & -4.85 \\
\hline FF American blend & $35 \rightarrow 400$ & 0.81 & $1.80 \times 10^{-5}$ & -4.75 \\
\hline FF American blend (-EE) & $35 \rightarrow 400$ & 0.59 & $2.47 \times 10^{-5}$ & -4.61 \\
\hline FF American blend (+EE) & $35 \rightarrow 60$ & 0.024 & $9.17 \times 10^{-5}$ & -4.04 \\
\hline FF American blend & $35 \rightarrow 60$ & 0.014 & $1.57 \times 10^{-4}$ & -3.80 \\
\hline FF American blend (-EE) & $35 \rightarrow 60$ & 0.004 & $5.50 \times 10^{-4}$ & -3.26 \\
\hline FF American blend $+20 \% \mathrm{FV}^{\mathrm{c}}(+\mathrm{EE})$ & $35 \rightarrow 60$ & 0.088 & $4.54 \times 10^{-5}$ & -4.34 \\
\hline FF American blend $+20 \%$ FV & $35 \rightarrow 60$ & 0.051 & $7.84 \times 10^{-5}$ & -4.11 \\
\hline FF American blend $+20 \%$ FV $(-$ EE) & $35 \rightarrow 60$ & 0.014 & $2.86 \times 10^{-4}$ & -3.54 \\
\hline Cambridge Lowest 100s & none & 0.75 & $1.68 \times 10^{-5}$ & -4.77 \\
\hline Merit Ultra KS & none & 0.24 & $2.28 \times 10^{-5}$ & -4.64 \\
\hline Marlboro Lights KS & none & 0.06 & $3.72 \times 10^{-5}$ & -4.42 \\
\hline Industry Monitor 16 & none & 0.02 & $6.94 \times 10^{-5}$ & -4.16 \\
\hline
\end{tabular}

${ }^{\text {a }} \mathrm{FF}=$ Full flavor

${ }^{b}$ EE is the experimental error reported for the values reported by JOSEPH and COCHRAN (43)

${ }^{c} \mathrm{FV}=$ Filter ventilation

lated product to $0.02 \%$ for a nonventilated product. The corresponding estimates for $\log K_{\mathrm{p}}$ ranged from -4.77 to -4.16. These estimates may be high because no allowance has been made for gas-phase nicotine that may have been retained by the Cambridge pad (34). While the data from KINSER et al. showed somewhat lower values for $K_{\mathrm{p}}$ than did the work of JOSEPH and COCHRAN, both studies point to values for $\log K_{\mathrm{p}}$ of between -4 and -5 for contemporary American products. Indeed, PANKOW reported $\log K_{\mathrm{p}}$ to be -4.43 for the TPM of MSS-A when his desorption experiments were carried out without the use of ammonia in the desorption gas. Also, the increases in $P_{\mathrm{g}}(\%)$ with increases in filter ventilation have also been confirmed by MARINER and FROST (45).

As shown in Table 2, PANKOw had to use at least $40 \mathrm{~L}$ of desorption gas containing $80.4 \mathrm{ppmV}$ ammonia to achieve a $\log K_{\mathrm{p}}$ of -4.8 for MSS-A. This corresponded to $2273 \mu \mathrm{g}(134 \mu \mathrm{mol})$ of ammonia for $550 \mu \mathrm{g}(3.4 \mu \mathrm{mol})$ of nicotine. To achieve what PANKOW called his "full ammonia effect" $\left(\log K_{\mathrm{p}}=-4.94\right)$, he had to use at least $5229 \mu \mathrm{g}(308 \mu \mathrm{mol})$ of ammonia for the same $550 \mu \mathrm{g}$ $(3.4 \mu \mathrm{mol})$ of nicotine. PANKOW made much of the "full ammonia effect" as the data in Table 2 show that when large amounts of ammonia were used, the values of $\log K_{\mathrm{p}}$ for all three samples tended to reach a value of around -4.9 to -5.0 . PANKOW assumed that a $\log K_{\mathrm{p}}$ of -4.94 for nicotine in MSS at $20^{\circ} \mathrm{C}$ meant that $\alpha_{\mathrm{fb}} \sim 1$. PANKOW then stated that by Equation [2.8], when the $K_{\mathrm{p}}$ for MSS with the "full ammonia effect" is divided by the $K_{\mathrm{p}}$ for the MSS with "no ammonia effect" (remember that the "no ammonia effect" value was taken from an ETS that was flawed) that $\alpha_{\mathrm{fb}}=10^{-2.11}$ as shown in Equation [2.11].

$$
\alpha_{\mathrm{fb}}=\frac{10^{-4.94}}{10^{-2.83}}=10^{-2.11}
$$

PANKOW then used Equation [2.5] to calculate a smoke $\mathrm{pH}$ of 5.91. However, from the recent work of just cited $(42,43,44)$ and from that of LEWIS, COLBECK, and MARINER (46) on the diluted MSS from a commercial cigarette that delivered $13 \mathrm{mg}$ "tar" and $1.2 \mathrm{mg}$ nicotine $(46,47)$, which PANKOW cited and used to calculate a $K_{\mathrm{p}}$ of $10^{-5.08}$, it is known that $K_{\text {for }}$ for nicotine in tobacco smoke could be less than $10^{-4.94}$. If it is assumed that the cigarette used by LEWIS et al. had a TPM pH of 6 (42), then by Equation [2.2] $\alpha_{\mathrm{fb}}=10^{-2.02}$. Then, by rearranging Equation [2.8] to give Equation [2.12], $K_{\mathrm{p}, \mathrm{fb}}$ can be calculated as follows assuming a $K_{\mathrm{p}}$ of $10^{-5.08}$.

$$
\alpha_{\mathrm{fb}}\left(K_{\mathrm{p}}\right)=10^{-2.02} \cdot 10^{-5.08}=10^{-7.10}=K_{\mathrm{p}, \mathrm{fb}}
$$

As Equation [2.12] shows, PANKOW not only erred in using his baseline value of $\log K_{\mathrm{p}}$ of -2.83 to represent MSS from a cigarette that had no ammonia treatment even though that value was determined on ETS and (as shown above) was incorrect even for ETS, but he also erred in his estimation of $K_{\mathrm{p}, \mathrm{fb}}$.

Also, PANKOw had data to indicate that for MSS-A, when no ammonia was used in the desorption gas, $\log K_{\mathrm{p}}$ was -4.43. Indeed, if he had used his own work on absorptive partitioning (3) and common knowledge of the major smoke components of commercial cigarettes [TPM, water, nicotine, glycerol, propylene glycol, neophytadiene, phenol, acetic acid, menthol (if present), and triacetin (if a filter cigarette and the filter contained triacetin)] $(48,49,50,51,52,53,54)$, he could have estimated $K_{\mathrm{p}}$ by Equation [1.6]. Indeed, if PANKOw had 
Table 4.

Summary of calculated values of $y$ for nicotine in MSS for a nonventilated filtered US-blend cigarette $(42,43)$

\begin{tabular}{|c|c|c|c|c|}
\hline Cigarette & Per puff dilution & $P_{g}(\%)$ & $K_{\mathrm{p}}\left(\mathrm{m}^{3} / \mathrm{ug}\right)$ & $\mathrm{Y}^{\mathrm{c}}$ \\
\hline FF $^{\mathrm{a}}$ American blend & $35 \rightarrow 400$ & 0.96 & $1.51 \times 10^{-5}$ & 0.67 \\
\hline FF American blend $(+E E)^{b}$ & $35 \rightarrow 400$ & 1.03 & $1.41 \times 10^{-5}$ & 0.71 \\
\hline FF American blend & $35 \rightarrow 400$ & 0.81 & $1.80 \times 10^{-5}$ & 0.56 \\
\hline FF American blend (-EE) & $35 \rightarrow 400$ & 0.59 & $2.47 \times 10^{-5}$ & 0.41 \\
\hline FF American blend (+EE) & $35 \rightarrow 60$ & 0.024 & $9.17 \times 10^{-5}$ & 0.11 \\
\hline FF American blend & $35 \rightarrow 60$ & 0.014 & $1.57 \times 10^{-4}$ & 0.06 \\
\hline FF American blend (-EE) & $35 \rightarrow 60$ & 0.004 & $5.50 \times 10^{-4}$ & 0.02 \\
\hline
\end{tabular}

${ }^{\mathrm{a}} \mathrm{FF}=$ Full flavor

${ }^{\mathrm{b}} \mathrm{EE}$ is the experimental error reported for the values reported by JOSEPH and COCHRAN (43)

${ }^{\mathrm{c}} \mathrm{A}$ value of $1.0 \times 10^{-5} \mathrm{~m}^{3} / \mathrm{\mu g}$ at $25^{\circ} \mathrm{C}$ has been used for the calculated value of $K_{\mathrm{p}}$ using Equation [1.6]

done that for cigarettes of the type he used, he would have found a value for $K_{\mathrm{p}}$ of $1.8 \times 10^{-5}\left(\log K_{\mathrm{p}}=-4.7\right)$. Some comments about this estimation are in order: (A) $f_{\text {om }}$ has been assumed to be unity based on PANKOW's use of Equation $[1.6](7,19)$; (B) data on TPM, water, nicotine, and the other major smoke components (FTC conditions) along with PANKOW's assumption about the general MW of smoke [a value of $250 \mathrm{~g} / \mathrm{mol}$ was used for the uncharacterized part of smoke, (7)] are needed to estimate $\mathrm{MW}_{\mathrm{om}}$; $(\mathrm{C})$ the vapor pressure of nicotine is needed for $p_{\mathrm{L}}^{\circ}$ and a value of 0.012 torr $\left(20^{\circ} \mathrm{C}\right)$ was used (55); and (D) an activity coefficient of unity was assumed. However, if this calculated $K_{\mathrm{p}}$ of $10^{-4.7}$ is checked for reasonableness by calculating $\alpha_{\mathrm{fb}}$, a value of $10^{-2.4}$ is found using a value of $10^{-7.10}$ for $K_{\mathrm{p}, \mathrm{fb}}$. When the value for $\alpha_{\mathrm{fb}}$, of $10^{-2.4}$ is substituted into Equation [2.2], the estimated $\mathrm{pH}$ is 5.7. This is a very reasonable value given all the asumptions that have been made $\left(56,57^{\mathrm{a}}\right)$.

With the experimental data from JOSEPH and COCHRAN $(42,43)$, it is possible to estimate the activity coefficient for nicotine in TPM. If it is assumed that all factors are constant between the $K_{\mathrm{p}}$ estimated by Equation [1.6] (1.0 $\times 10^{-5} \mathrm{~m}^{3} / \mu \mathrm{g}$ at $25^{\circ} \mathrm{C}$ for a filtered, but not ventilated KS American blend product) and the values for $K_{\mathrm{p}}$ estimated from the experimental data for a similar product (Table 3) except for the activity coefficient, then the activity coefficient for nicotine in the TPM can also

a NOTE ADDED IN PROOF. The estimate of $10^{-7.10}$ for $K_{\mathrm{p}, \mathrm{fb}}$ versus PANKOW's estimate of $10^{-4.94}$ has taken on new importance. Very recently, PANKOW presented the following data (the method used and its accuracy and precision, not specified) for four unnamed brands of US cigarettes. $K_{\mathrm{p}}$ values: $10^{-2.60}, 10^{-3.60}, 10^{-4.60}$, and $10^{-4.65}$. Corresponding $\alpha_{\mathrm{fb}}$ values: $0.0045,0.045,0.45$, and 0.51 . Calculated MSS $\mathrm{pH}$ values: 5.7 , 6.7, 7.9, and 8.1. Calculations showed that these data were obtained with the estimate of $10^{-4.94}$ for $K_{\mathrm{p}, \mathrm{fb}}$. However, if the estimate of $10^{-7.10}$ for $K_{\mathrm{p}, \mathrm{fb}}$ is used, calculations give the corresponding $\alpha_{\mathrm{fb}}$ values: 0.000032 , $0.00032,0.0032$ and 0.0036 . Calculated MSS $\mathrm{pH}$ values: $3.52,4.52,5.52$, and 5.57. While the calculated smoke $\mathrm{pH}$ value of 3.52 may seem unreasonably low, it is based on the data that PANKOw presented. be estimated (17). These estimates are shown in Table 4, and they range from 0.02 to 0.71 . The values for $\gamma$ shown in Table 4 indicate that $\gamma$ probably does not remain constant as smoke is diluted. Also, the values for $\gamma$ estimated from the data on $P_{\mathrm{g}}(\%)$ of JOSEPH and COCHRAN (43) from their most recent experiments (each puff diluted from $35 \mathrm{~mL}$ to $60 \mathrm{~mL}$ prior to dilution) are in the same order of magnitude as the values reported by NORTON and co-workers (35) for aqueous nicotine solutions of about the same weight percentage that would be obtained from particulate-phase nicotine dissolved in particulate-phase water.

The data in Tables 3 and 4 show that if PANKOw's hypothesis about $K_{\mathrm{p}, \mathrm{fb}}$ is correct, then $\alpha_{\mathrm{fb}}$ is changing as MSS is diluted as required by experimentation to determine $P_{g}(\%)(42,43,45,46,47)$ or through changes in cigarette design including filter ventilation $(43,44,45)$. Since PANKOW related $\alpha_{\mathrm{fb}}$ to smoke $\mathrm{pH}$ (method not defined), and since $\alpha_{\mathrm{fb}}$ must increase as $K_{\mathrm{p}}$ decreases if $K_{\mathrm{p}, \mathrm{fb}}$ is constant by Equation [2.8], then $\alpha_{\mathrm{fb}}$ should increase with filter ventilation. This effect has been shown experimentally by MORIE and BAGGETT (58). Filter ventilation not only reduces $K_{\mathrm{p}}$ through a decrease in TSP by Equation [1.1], but it also may cause $\gamma$ to increase.

It must be pointed out that there were two other errors in PANKOW's use of ammonia in the desorption gas to simulate the basicity of MSS ammonia. While ammonia is predominately in the gas phase of smoke, although some is found in the particulate phase (59), most of the ammonia in smoke is protonated (60). Thus, PANKOW's use of fully unprotonated ammonia was not appropriate. Also, he should also have added carbon dioxide to his desorption gas. There are relatively large amounts of carbon dioxide in the gas phase of smoke $(61,62)$ along with relatively large quantities of gas-phase water (63, 64). These lead to the formation of nascent carbon dioxide and the reduction of smoke $\mathrm{pH}(65)$. 
Table 5.

Corrected calculated values for the fraction $\boldsymbol{P}_{\mathrm{g}, \mathrm{eq}}(\%)$ of nicotine on dilution of MSS

\begin{tabular}{|c|c|c|c|}
\hline Smoke type & $\mathrm{TSP}\left(\mu \mathrm{g} / \mathrm{m}^{3}\right)$ & $\log K_{\mathrm{p}}\left(\mathrm{m}^{3} / \mu \mathrm{g}\right)$ & $P_{\mathrm{g}, \mathrm{eq}}(\%)$ \\
\hline \multicolumn{4}{|c|}{$20^{\circ} \mathrm{C}$} \\
\hline MSS & $4.00 \times 10^{7}$ & -4.43 & 0.07 \\
\hline MSS/14 & $2.86 \times 10^{7}$ & -4.43 & 0.93 \\
\hline MSS/28 & $1.43 \times 10^{6}$ & -4.43 & 1.85 \\
\hline \multicolumn{4}{|c|}{$37^{\circ} \mathrm{C}$} \\
\hline MSS & $4.00 \times 10^{7}$ & -5.18 & 0.22 \\
\hline MSS/14 & $2.86 \times 10^{7}$ & -5.18 & 2.98 \\
\hline MSS/28 & $1.43 \times 10^{6}$ & -5.18 & 5.79 \\
\hline
\end{tabular}

In Table 5, PANKOW's assumption of a MSS TSP of $4 \times 10^{7} \mu \mathrm{g} / \mathrm{m}^{3}$ was used along with RAY's data on the vapor pressure of nicotine at $20^{\circ} \mathrm{C}$ and $37^{\circ} \mathrm{C}$. PANKOW's value of -4.43 for $\log K_{\mathrm{p}}$ at $20^{\circ} \mathrm{C}$ was used.

\section{Postulated effects in the smoker's lungs}

A key point in PANKOw's 1997 paper was that dilution of inhaled MSS by the tidal volume of air in a smoker's lungs increased the amount of unprotonated nicotine present in the smoke (8). He postulated that the tidal volume of air would give a dilution factor of 14 . He further postulated that diffusive mixing of the smoke with inhaled air would further dilute it by a factor of two for a total dilution factor of 28 . He also stated that because a smoker's lungs are at body temperature $\left(37^{\circ} \mathrm{C}\right)$ that $K_{\mathrm{p}}$ had to be adjusted for temperature as values of $K_{\mathrm{p}}$ are inversely proportional to vapor pressure (4). $\mathrm{He}$ further assumed that values of $K_{\mathrm{p}}$ for inhaled smoke would not change with dilution, and that the undiluted MSS from a cigarette without ammonia-containing additives would have a $\log K_{\mathrm{p}}$ of -2.83 . The results of these assumptions, which were given in Table 3 of Reference 8, led PANKOW to claim that the use of ammonia-containing additives would increase the unprotonated nicotine available to the smoker 100 -fold. Since that time, PANKOW discovered that he had made an error in his calculations and, as already mentioned (11), published corrections to his original paper. However, PANKOW's corrected data are still in error as he continued to use a value for $K_{\mathrm{p}}$ of $\log -2.83$ for nicotine in MSS at $20^{\circ} \mathrm{C}$. As shown in Table 3, this value is incorrect based on the experimental work of JOSEPH and COCHRAN $(42,43)$ and of KINSER et al. (44). Furthermore, as shown below, PANKOW's "ammonia effect" is not relevant as the vast majority of smoke ammonia goes to SSS. In Table 5, a more accurate presentation of the situation is given. In this Table, PANKOW's assumption of a MSS TSP of $4 \times$ $10^{7} \mu \mathrm{g} / \mathrm{m}^{3}$ was used along with RAY's data on the vapor pressure of nicotine at $20^{\circ} \mathrm{C}$ and $37^{\circ} \mathrm{C}$. PANKOW's value of -4.43 for $\log K_{\mathrm{p}}$ at $20^{\circ} \mathrm{C}$ was used.

PANKOW originally claimed that $P_{\text {g,eq }}(\%)$ for MSS at $37{ }^{\circ} \mathrm{C}$ that had been diluted 14-fold (MSS/14) would increase from $0.25 \%$ without added ammonia to $25 \%$ with added ammonia. More recently, PANKOW claimed that the increase was from $0.094 \%$ to $11 \%$, as the wrong factor was used to correct $K_{\mathrm{p}}$ for the temperature change from $25^{\circ} \mathrm{C}$ to $37^{\circ} \mathrm{C}$ (11). However, those data are still based on incorrect $K_{\mathrm{p}}$ values. When calculated correctly (Table 5), MSS $/ 28$ at $37{ }^{\circ} \mathrm{C}$ has an estimated $P_{\text {g,eq }}$ of $2.98 \%$. The calculated value for $P_{\text {g,eq }}(\%)$ of $0.93 \%$ for MSS $/ 14\left(\right.$ TSP $\left.=2.86 \times 10^{6} \mu \mathrm{g} / \mathrm{m}^{3}\right)$ at $20^{\circ} \mathrm{C}$ was quite close to the experimentally determined value of $0.96 \%$ for $P_{\text {geq }}(\%)$ at $25{ }^{\circ} \mathrm{C}$ that was reported by JOSEPH and COCHRAN for a TSP of around $6.81 \times 10^{6} \mu \mathrm{g} / \mathrm{m}^{3}(42)$.

\section{$V$. Generation and fate of smoke ammonia}

Another way to look at the issue of ammonia is to review what is known about the generation and fate of smoke ammonia. Smoke ammonia comes from several sources: (A) the pyrolysis of proteins and other organic nitrogen compounds in the blend (66); (B) the conversion of nitrate during the smoking process $(67,68) ;(C)$ the decomposition of ammonia-containing additives that may not be consumed by reactions with other tobacco components if such additives are used; and residual ammonia in the blend from the use of ammonia-containing additives.

While there appears to be no references in the peer-reviewed literature as to the levels of unreacted ammonia-containing additives in commercial cigarettes, information does exist as to the residual ammonia levels in commercial cigarette products and that information comes from work commissioned by the Massachusetts Department of Public Health (69). The work commissioned by the Massachusetts Department, and which was performed by Labstat, Inc., included determinations of both blend ammonia and smoke ammonia as well as smoke $\mathrm{pH}$ by the technique developed by SENSABAUGH and CUNDIFF (70). Two of the products tested were the same brand styles as used by PANKOW. The relevant data 
Table 6.

Blend ammonia, MSS ammonia and MSS pH for selected American cigarettes (69)

\begin{tabular}{l|c|c|c|c}
\hline Brand style & FTC "tar" (mg/cig) & Tobacco NH $\left.\mathrm{N}_{3} \%\right)$ & ${\text { Smoke } \mathrm{NH}_{3}(\mu \mathrm{g} / \mathrm{cig})}_{\mathrm{Smoke} \mathrm{pH}}$ \\
\hline Camel KS (MSS-B) & 14 & 0.11 & 33 & 6.00 \\
Camel Lights KS & 9 & 0.13 & 21 & 6.07 \\
Camel Ultra Lights KS & 5 & 0.12 & 13 & 6.35 \\
Marlboro KS (MSS-A) & 16 & 0.27 & 32 & 6.03 \\
Marlboro Lights KS & 10 & 0.28 & 22 & 6.13 \\
Merit Filters 100s & 9 & 0.29 & 19 & 6.33 \\
Merit Ultra Light KS & 5 & 0.34 & 12 & 6.33 \\
\hline
\end{tabular}

from the Massachusetts report (Table 6) show that for the two brands that PANKOW used as well as the other brands tested that there is no relationship between tobacco ammonia and smoke ammonia. Also, there appears to be no relationship between either tobacco ammonia or smoke ammonia and smoke $\mathrm{pH}$. The Massachusetts findings are also supported by findings presented by ELLIS et al. (71).

The main reason for this is that the major part of smoke ammonia emerges as SSS, and SSS ammonia/MSS ammonia ratios of $150 / 1$ or more are typical for contemporary US-blend filter cigarettes (72). Indeed, for the Kentucky 1R4F reference cigarette (73), the MSS ammonia delivery has been reported to be $18 \mu \mathrm{g} /$ cigarette (74); however, the SSS ammonia delivery on the $1 \mathrm{R} 4 \mathrm{~F}$ has been reported to range between 7200 and $9100 \mu \mathrm{g} /$ cigarette $(74,75)$ for a SSS/MSS ratio of 400:1 or greater. Another reason for the lack of correlation between the use of tobacco ammoniation processes and smoke ammonia is that ammonia and its salts react with the reducing sugars in the tobacco to yield sugar-ammonia reaction products. This has been shown by work with ammonia sources labeled with ${ }^{15} \mathrm{~N}$ followed by analysis of the sugar-ammonia reaction products by GC/MS $(76,77)$. Tobacco ammoniation is a common way to introduce flavors and flavor precursors through the use of the Maillard reaction $(78,79)$. Such reactions are well known in both the tobacco and food industries $(80,81)$, and except in the case of urea (82), most of the ammonia-containing reactants will be consumed as long as an excess of reducing sugars is maintained $(83,84)$.

PANKOW stated that reconstituted tobacco could be used at up to $30 \%$ of the tobacco blend and that up to $10 \%$ of such reconstituted tobacco could contain ammonia-containing materials such as diammonium phosphate (DAP) or urea. If it is assumed that lights products such as represented by the Kentucky 1R4F reference cigarette (73) has properties similar to many contemporary commercial products on the US market, then the effects on MSS ammonia can be calculated. In the examples shown in Tables 7, 8, and 9, PANKOW's levels of ammonia-containing compounds are assumed along with a tobacco weight similar to that reported for the $1 \mathrm{R} 4 \mathrm{~F}(85)$ and the
400/1 SSS/MSS ammonia distribution mentioned earlier. The data in these tables show that at a maximum, which would represent no reaction of ammonia-containing chemicals with other blend components, the MSS ammonia level would rise from $18 \mu \mathrm{g} /$ cigarette to 51 $\mu \mathrm{g} /$ cigarette. The value of $51 \mu \mathrm{g} /$ cigarette is well within the range reported for domestic products (60). It should be noted that none of the Kentucky reference cigarettes manufactured to date has used any ammonia-containing compounds (85).

\section{Bioavailability of nicotine in aerosols}

One of the key arguments that PANKOW used to support his conclusions as well as attract media attention was to tie his conclusions on the $\mathrm{pH}$ of MSS to those of $\mathrm{BURCH}$ et al. on the bioavailability of nicotine in nicotine/saline aerosols (86). BURCH's work was an extension of his previous work (87) and that of LUX and FRECKER (88) to develop palatable and effective nicotine aerosols for smoking-cessation programs. BURCH exposed volunteer smokers to nicotine/saline aerosols that were prepared at $\mathrm{pH}$ 5.6, 7.5, and 11. He then measured the plasma nicotine levels periodically. The error in BURCH's work was that the different groups of smokers started at different baseline levels of plasma nicotine (subjects only abstained from smoking for an hour before the experiments). BURCH found no statistically significant difference $(p=0.051)$ between the plasma nicotine levels for the aerosol made from a nicotine/saline solution at $\mathrm{pH}$ 5.6 and those for the aerosol made from a nicotine/saline solution at $\mathrm{pH}$ 7.5. However, it might be argued that there was a strong directional trend. Figure 2 in BURCH's article, which showed plots of plasma nicotine levels versus time, showed the curve for the nicotine/saline solution at $\mathrm{pH} 7.5$ at a higher level than that for the nicotine/saline solution at $\mathrm{pH}$ 5.6. However, when these curves were adjusted for the difference in baseline plasma nicotine levels, they were virtually indistinguishable. There only were statistically significant differences between the aerosols at $\mathrm{pH} 5.6$ and 11 and those at $\mathrm{pH}$ 7.5 and 11. Indeed, the times-to-peak plasma concentra- 
Table 7.

Calculated SSS and MSS ammonia deliveries assuming $100 \%$ transfer of all DAP ammonia to smoke from a hypothetical filter cigarette with a tobacco blend containing $30 \%$ RTS $^{\mathrm{b}}$ made with $10 \%$ DAP.

\begin{tabular}{ll}
\hline Tobacco or smoke parameter & Amount \\
\hline Tobacco weight of typical domestic cigarette & $767 \mathrm{mg}$ \\
Weight of RTS at $30 \%$ inclusion in tobacco blend & $230 \mathrm{mg}$ \\
Weight of DAP at 10\% of RTS & $23 \mathrm{mg}(0.174 \mathrm{mmol})$ \\
Weight of ammonia transferred to smoke assuming 100\% transfer and 2 moles & $5932 \mu \mathrm{g}$ \\
ammonia per mole DAP & 400 \\
Assumed SSS/MSS ratio & $5917 \mu \mathrm{g} /$ cigarette \\
SSS ammonia attributable to DAP & $15 \mu \mathrm{g} / \mathrm{cigarette}$ \\
\hline
\end{tabular}

${ }^{\mathrm{a}} \mathrm{DAP}=$ diammonium phosphate

${ }^{\mathrm{b}} \mathrm{RTS}=$ Reconstituted tobacco sheet

Table 8.

Calculated SSS and MSS ammonia deliveries assuming $100 \%$ transfer of all urea ammonia to smoke from a hypothetical filter cigarette with a tobacco blend containing $30 \%$ RTS made with $10 \%$ urea

\begin{tabular}{ll}
\hline Tobacco or smoke parameter & Amount \\
\hline Tobacco weight of typical domestic cigarette & $767 \mathrm{mg}$ \\
Weight of RTS at $30 \%$ inclusion in tobacco blend & $230 \mathrm{mg}$ \\
Weight of urea at $10 \%$ of RTS & $23 \mathrm{mg}(0.383 \mathrm{mmol})$ \\
Weight of ammonia transferred to smoke assuming 100\% transfer and 2 moles & $13020 \mu \mathrm{g}$ \\
ammonia per mole urea & 400 \\
Assumed SSS/MSS ratio & $12987 \mu \mathrm{g} /$ cigarette \\
SSS ammonia attributable to urea & $33 \mu \mathrm{g} /$ cigarette \\
MSS ammonia attributable to urea & \\
\hline
\end{tabular}

Table 9.

Calculated SSS and MSS ammonia deliveries assuming $100 \%$ transfer of all DAP ammonia to smoke from a hypothetical filter cigarette with a tobacco blend containing $30 \%$ RTS made with 10\% DAP after accounting for reactions with reducing sugars

\begin{tabular}{ll}
\hline Tobacco or smoke parameter & Amount \\
\hline Tobacco weight of typical domestic cigarette & $767 \mathrm{mg}$ \\
Weight of RTS at $30 \%$ inclusion in tobacco blend & $230 \mathrm{mg}$ \\
Weight of DAP at $10 \%$ of RTS & $23 \mathrm{mg}(0.174 \mathrm{mmol})$ \\
Weight of available ammonia & $5932 \mu \mathrm{g}(0.348 \mathrm{mmol})$ \\
Weight of reducing sugars in tobacco at $5 \%$ of tobacco weight & $38 \mathrm{mg}(0.213 \mathrm{mmol})$ \\
Weight of ammonia consumed by reaction with sugars & $3625 \mu \mathrm{g}(0.213 \mathrm{mmol})$ \\
Weight of remaining ammonia available for transfer to smoke and assuming & $2307 \mu \mathrm{gg}$ \\
$100 \%$ transfer & 400 \\
Assumed SSS/MSS ratio & $2301 \mu \mathrm{g} / \mathrm{cigarette}$ \\
SSS ammonia attributable to DAP & $6 \mu \mathrm{g} / \mathrm{cigarette}$ \\
MSS ammonia attributable to DAP & \\
\hline
\end{tabular}

${ }^{a}$ Calculated as glucose and/or fructose, mw 180

tions were not dependent on the $\mathrm{pH}$ of the solutions used to make the aerosols.

It must also be pointed out that the mass median diameters for BURCH's aerosols were much larger than those typically reported for MSS and the amount of nicotine delivered was four to five times that of the typical cigarette. In addition, the use of BURCH's data was inappropriate because the $\mathrm{pH}$ 's of 7.5 and 11 are far above 
those found in cigarette smoke as even PANKOW agreed that smoke is acidic. From a purely scientific point of view, PANKOW's use of BURCH's data was inappropriate as aerosols that are based on sodium chloride undergo adsorptive partitioning as PANKOW has reported (89), but cigarette smoke aerosols undergo absorptive partitioning as he also reported (7). If, on the other hand, absorptive partitioning were assumed, the estimated $K_{\mathrm{p}}$ for BURCH's aerosol at neutral $\mathrm{pH}$ would be about $2.7 \times 10^{-6} \mathrm{~m}^{3} / \mu \mathrm{g}(\gamma$ assumed to be $0.26, f_{\text {om }}$ calculated to be 0.13 as water, in this case, not assumed to be part of the absorbing organic matter). This is about an order of magnitude less than that estimated for cigarette smoke; and hence, more of the nicotine would be in the gas phase of the aerosol.

Another paper relevant to BURCH's work was that of HÄGER and NIESSNER on the amount of gas-phase nicotine in synthetic aerosols (90). These authors found that a dehydrated nicotine aerosol (TSP $=4.8 \mathrm{mg} / \mathrm{m}^{3}$ ) had $87.6 \pm 7.3 \%$ of the nicotine in the gas phase of the aerosol. In other experiments, various acids, salts, and neutral materials were added to the nicotine solution used to form the aerosols. $P_{\mathrm{g}}(\%)$ ranged from about $9 \%$ (acidic additives) to over $90 \%$ (neutral additives such as glycerol or triacetin). While such results might be used to support PANKOW's hypothesis, the TSP levels used were on the order of those found in ETS; and thus, the high values for $P_{\mathrm{g}}(\%)$ are not unexpected.

\section{Analogy to cocaine}

PANKOW also claimed that smoking cigarettes made with ammoniated tobaccos was analogous to "free-basing" cocaine or smoking "crack" cocaine. This point also attracted media attention $(9,10)$. However, PANKOW erred in his understanding of the chemistry of cocaine and its salts as well as that of nicotine and its salts. Cocaine salts are thermally unstable while those of nicotine are thermally stable. The major pyrolysis products of cocaine hydrochloride salt under the conditions expected for smoking have been reported to be a mixture of carbomethoxycycloheptatrienes and methylamine. The pyrolysis of crack (cocaine hydrochloride plus sodium bicarbonate) under similar conditions reportedly gave methylecgonidine as the major product (91).

High yields of cocaine in pyrolyzates have been reported only when cocaine hydrochloride was treated with strong base and the completely unprotonated cocaine extracted into ether, and the extract pyrolyzed (92). This is in sharp contrast to nicotine, most of whose salts readily yield unprotonated nicotine on heating with little or no decomposition of the nicotine moiety $(93,94,95,96)$. Also, through his reference to a book on cocaine abuse (97) PANKOW attempted to link the pharmacology and pharmacokinetics of unprotonated nicotine with unprotonated cocaine. However, for absorption in the small airways and the lungs the degree of protonation of nicotine is irrelevant $(98,99)$.

\section{CONCLUSIONS}

This review has pointed out the strong points and weak points of PANKOW's use of gas/particle partitioning experiments and the theory of gas/particle partitioning to explain the behavior of nicotine in cigarette MSS and ETS. While PANKOW's theoretical approaches are applicable to cigarette smoke if equilibrium (albeit dynamic) is assumed, his experimental attempts to determine the gas/particle partitioning coefficient, $K_{\mathrm{p}}$, for nicotine in MSS and ETS, were flawed.

This review also has shown that PANKOw's experimentally determined $K_{\mathrm{p}}$ of $10^{-2.83} \mathrm{~m}^{3} / \mu \mathrm{g}$ for nicotine in ETS was incorrect. More importantly, his use of this same $K_{\mathrm{p}}$ value for nicotine in MSS also was incorrect. This was shown to be the case through the use of PANKOw's own equation to describe gas/particle partitioning when the partitioning is predominately absorptive, through analysis of PANKOW's own experimental data, and through comparisons of PANKOW's work with those of other researchers. Likewise, errors were also found in PANKOW's estimation in the amount of gas-phase nicotine present when MSS is inhaled by a smoker and that PANKOW significantly overestimated the amount of gas-phase nicotine that would be present in inhaled MSS. Finally, this review showed through the use of examples from the literature that the use of ammonia-containing tobacco additives does not significantly alter MSS ammonia levels and hence does not increase smoke $\mathrm{pH}$ or the amount of unprotonated nicotine available to the smoker.

\section{GLOSSARY}

$\alpha_{\mathrm{fb}}=$ Fraction of particulate-phase nicotine that is unprotonated

$\gamma_{\mathrm{i}}=$ Activity coefficient of a compound $(\imath)$ in the particulate phase

$\varphi=$ Fraction of a compound that is in the particulate phase of an aerosol

$c_{\mathrm{p}, \mathrm{fb}}=$ Concentration of unprotonated nicotine in the particulate phase $(\mathrm{ng} / \mu \mathrm{g})$

$c_{\mathrm{g}}=$ Concentration of nicotine (assumed to be unprotonated) in the gas phase $\left(\mathrm{ng} / \mathrm{m}^{3}\right)$

$c_{\mathrm{p}}=$ Total nicotine concentration in the particulate phase $(\mathrm{ng} / \mu \mathrm{g})$

$f_{\text {om }}=$ Fraction of organic matter in the particulate phase

$p_{\mathrm{L}, \mathrm{i}}^{\circ}=$ Vapor-pressure of a pure compound $(i)$ as a liquid at the temperature of interest (torr)

$t_{0}=$ Molecular vibration time (second)

$A_{\text {tsp }}=$ Specific surface area of an aerosol $\left(\mathrm{cm}^{2} / \mu \mathrm{g}\right)$

$A=$ Equilibrium concentration of a given component in the gas phase of an aerosol $\left(\mathrm{ng} / \mathrm{m}^{3}\right)$ 
$F=$ Equilibrium concentration of a given component in the particulate phase of an aerosol $\left(\mathrm{ng} / \mathrm{m}^{3}\right)$

$K_{\mathrm{p}, \mathrm{fb}}=$ Gas/particle partitioning coefficient for unprotonated nicotine in an aerosol

$K_{\mathrm{p}} \quad=$ Gas/particle partitioning coefficient $\left(\mathrm{m}^{3} / \mu \mathrm{g}\right)$

$M_{\mathrm{p}} \quad=$ Net weight of particulate matter in a sample of an aerosol $(\mu \mathrm{g})$

$M_{\mathrm{e}} \quad=\quad$ Net weight of analyte in known weight of aerosol particulate matter $(\mu \mathrm{g})$

$M_{\mathrm{t}} \quad=$ Weight of analyte desorbed in a given time period $(\mu \mathrm{g})$

$\mathrm{MW}_{\mathrm{om}}=$ Number average molecular weight of the particulate phase

$N_{s} \quad=$ Adsorption sites in an aerosol (sites $/ \mathrm{cm}^{2}$ )

$P_{\mathrm{g}}(\%)=$ Percent of total smoke nicotine that is in the gas-phase

$Q_{1}=$ Energy of desorption from the surface of the aerosol $\left(\mathrm{kJ} / \mathrm{mol}^{-1}\right)$

$Q_{\mathrm{v}} \quad=\quad$ Energy of vaporization for a component of interest in the aerosol $\left(\mathrm{kJ} / \mathrm{mol}^{-1}\right)$

$\mathrm{R}=$ Gas constant $\left(8.2 \times 10^{-5} \mathrm{~m}^{3}\right.$ atm mol$\left.{ }^{-1} \mathrm{~T}^{-1}\right)$

$T=$ Temperature $\left({ }^{\circ} \mathrm{K}\right)$

TSP $=$ Equilibrium concentration of total suspended particulate matter in the aerosol $\left(\mu \mathrm{g} / \mathrm{m}^{3}\right)$

\section{REFERENCES}

1. Goss, K-U. and R.P. Schwarzenbach: Gas/solid and gas/liquid partitioning of organic compounds: Critical evaluation of the interpretation of equilibrium constants; Environ. Sci. Technol. 32 (1998) 2025-2032.

2. Pankow, J.F.: Review and comparative analysis of the theories of partitioning between the gas and aerosol particulate phases in the atmosphere; Atmospheric Environ. 21 (1987) 2275-2283.

3. Pankow, J.F.: An absorption model of gas/particle partitioning of organic compounds in the atmosphere; Atmospheric Environ. 28 (1994) 185-183.

4. Pankow, J.F.: An absorption model of the gas/aerosol partitioning involved in the formation of secondary organic aerosol; Atmospheric Environ. 28 (1994) 189-193.

5. Pankow, J.F., L.M. Isbelle, D.A. Buchholz, W.T. Luo, and B.D. Reeves: Gas/particle partitioning of polycyclic aromatic hydrocarbons and alkanes to environmental tobacco smoke; Environ. Sci. Technol. 28 (1994) 363-365.

6. Liang, C. and J.F. Pankow: Gas/particle partitioning of organic compounds to environmental tobacco smoke: Partition measurements by desorption; Amer. Chem. Soc., Div. Environ. Chem. Preprints of Extended Abstracts 36 (1996) 318-320.

7. Liang, C. and J.F. Pankow: Gas/particle partitioning of organic compounds to environmental tobacco smoke: Partition coefficient measurements by desorption and comparison to urban particulate matter; Environ. Sci. Technol. 30 (1996) 2800-2805

8. Pankow, J.F., B.T. Mader, L.M. Isabelle, W. Luo, A. Pavlick, and C. Liang: Conversion of nicotine in tobacco smoke to its volatile and available form through the action of gaseous ammonia; Environ. Sci. Technol. 31 (1997) 2428-2433.

9. Schwartz, J.: Ammonia amplifies nicotine, study confirms; The Washington Post, July 30, 1997, A04.

10. Anonymous: Ammonia's effect on nicotine in cigarette smoke elucidated; Chem. Eng. News, August 4, 1997, p 45.

11. Pankow, J.F., B.T. Mader, L.M. Isabelle, W. Luo, A. Pavlick, and C. Liang: Conversion of nicotine in tobacco smoke to its volatile and available form through the action of gaseous ammonia; Environ. Sci. Technol. 33 (1999) 1320.

12. Yamasaki, H., K. Kuwata, and H. Miyamoto: Effects of ambient temperature on aspects of airborne polycyclic aromatic hydrocarbons; Environ. Sci. Technol. 16 (1982) 189-194.

13. Pankow, J.F.: Common y-intercept and single compound regressions of gas-particle partitioning data vs 1/T; Atmospheric Environ. 25A (1991) 2229-2239.

14. Pankow, J.F.: Application of common y-intercept regression parameters for $\log \mathrm{Kp}$ vs $1 / \mathrm{T}$ for predicting gas-particle partitioning in the urban environment; Atmospheric Environ. 26A (1992) 2489-2497.

15. Jang, M., R.M. Kamens, K.B. Leach, and M.R. Strommen: A thermodynamic approach using group contribution methods to model the partitioning of semivolatile organic compounds in atmospheric particulate matter; Environ. Sci. Technol. 31 (1997) 2805-2811.

16. Strommen, M.R. and R.M. Kamens: Development and application of a dual-impedance radial diffusion model to simulate the partitioning of semivolatile organic compounds in combustion aerosols; Environ. Sci. Technol. 31 (1997) 2983-2990.

17. Jang, M. and R.M. Kamens: A thermodynamic approach for modeling partitioning of semivolatile organic compounds on atmospheric particulate matter: Humidity effects; Environ. Sci. Technol. 32 (1998) 1237-1243.

18. Rounds, S.A., B.A. Tiffany, and J.F. Pankow: Description of gas/particle sorption kinetics with an intraparticle diffusion model: Desorption experiments; Environ. Sci. Technol. 27 (1993) 366-377.

19. Pankow, J.F.: Further discussion of the octanol/air partition coefficient $\mathrm{K}_{\mathrm{oa}}$ as a correlating parameter for gas/particle partitioning coefficients; Atmospheric Environ. 32 (1998) 1493-1497.

20. Vekris, S.L. and R.G. Hook: The distribution of substances between the vapor and particulate phases of cigarette smoke; $20^{\text {th }}$ Tobacco Chemists' Re- 
search Conference, Program Booklet and Abstracts, Vol. 20, No. 7, 1966, p. 27-29.

21. Lyman, W.J., W.F. Reehl, and D.H. Rosenblatt: Handbook of chemical property estimation methods; American Chemical Society, Washington, DC, 1990, Chapter 14, pp 1-20.

22. Liang, C.: Understanding the mechanisms of gas/particle partitioning of semi-volatile organic compounds to model inorganic aerosols, model organic aerosols, and urban particulate matter; Ph.D. Dissertation, Oregon Graduate Institute of Science \& Technology, 1997, 162 pp.

23. Caka, F.M., D.J. Eatough, E.A. Lewis, H. Tang, S.K. Hammond, B.P. Leaderer, M.W. Ogden, and J. Lewtas: An intercomparison of sampling techniques for nicotine in indoor environments; Environ. Sci. Technol. 24 (1990) 1196-1203.

24. Eudy, L.W., F.A. Thome, D.L. Heavner, C.R. Green, and B.J. Ingebrethsen: Studies on the vapor-particulate phase distribution of environmental nicotine by selected trapping and detection methods; $39^{\text {th }}$ Tobacco Chemists' Research Conference, Program Booklet and Abstracts, Vol. 39, No. 38, 1985, p. 20.

25. Eudy, L.W., F.A. Thome, D.L. Heavner, C.R. Green, and B.J. Ingebrethsen: Studies on the vapor-particulate phase distribution of environmental nicotine by selective trapping and detection methods; $79^{\text {th }}$ Annual Meeting of the Air Pollution Control Association, June 1986, Minneapolis, MN, 5 (1986) Paper 86-38-7.

26. Eatough, D.J., C. Benner, R.L. Mooney, D. Bartholomew, D.S. Steiner, L.D. Hansen, J.D. Lamb, and E.A. Lewis: Gas and particle phase nicotine in environmental tobacco smoke; $79^{\text {th }}$ Annual Meeting of the Air Pollution Control Association, June 1986, Minneapolis, MN, 5 (1986) Paper 86-68-5.

27. Leaderer, B.P. and S.K. Hammond: Evaluation of vapor-phase nicotine and respirable suspended particle mass as markers for environmental tobacco smoke; Environ. Sci. Technol. 25 (1991) 770-777.

28. Grubner, O., M.W. First, and G.L. Huber: Gas chromatographic determination of nicotine in gases and liquids with suppression of adsorption effects; Anal. Chem. 52 (1980) 1755-1758.

29. Ogden, M.W., L.W. Eudy, D.L. Heavner, F.W. Conrad Jr., and C.R. Green: Improved gas chromatographic determination of trace levels of environmental nicotine; $40^{\text {th }}$ Tobacco Chemists' Research Conference, Program Booklet and Abstracts, Vol. 40, No. 41, 1986, p. 22.

30. Ogden, M.W., L.W. Eudy, D.L. Heavner, F.W. Conrad, Jr., and C.R. Green: Improved gas chromatographic determination of nicotine in environmental tobacco smoke; Analyst 114 (1989) 1005-1008.

31. Eatough, D.J., C.L. Benner, J.M. Bayona, F.M. Caka, H. Tang, L. Lewis, J.D. Lamb, M.L. Lee, E.A.
Lewis, and L.D. Hanson: Sampling for gas phase nicotine in environmental tobacco smoke with a diffusion denuder and a passive sampler; Proceedings of the 1987 EPA/APCA Symposium on Measurement of Toxic and Related Air Pollutants, Air Pollution Control Association, Research Triangle Park, NC, May 1987.

32. Eatough, D.J., C.L. Benner, L.D. Hansen, and E.A. Lewis: Determination of the phase distribution of semi-volatile organic compounds with diffusion denuders; $80^{\text {th }}$ Annual Meeting of the Air Pollution Control Association, New York, NY, June 1987.

33. Eatough, D.J., C.L. Benner, J.M. Bayona, G. Richards, J.D. Lamb, M.L. Lee, E.A. Lewis, and L.D. Hansen: Chemical composition of environmental tobacco smoke. 1. Gas-phase acids and bases; Environ. Sci. Technol. 23 (1989) 679-687.

34. Ogden, M.W., K.C. Maiolo, P.R. Nelson, D.L. Heavner, and C.R. Green: Artefacts in determining the vapour-particulate phase distribution of environmental tobacco smoke nicotine; Environ. Tech. 14 (1993) 779-785.

35. Norton, L.B., C.R. Bigelow, and W.B. Vincent: Partial vapor pressures from nicotine solutions at 25; J. Amer. Chem. Soc. 62 (1940) 261-264.

36. Sakuma, H., M. Kusama, S. Munakata, T. Ohsumi, and S. Sugawara: The distribution of cigarette smoke components between mainstream and sidestream smoke. I. Acidic components; Beitr. Tabakforsch. Int. 12 (1983) 63-71.

37. Sakuma, H., M. Kusama, K. Yamaguchi, T. Matsuki, and S. Sugawara: The distribution of cigarette smoke components between mainstream and sidestream smoke. II. Bases; Beitr. Tabakforsch. Int. 12 (1984) 199-209.

38. Sakuma, H., M. Kusama, K. Yamaguchi, and S. Sugawara: The distribution of cigarette smoke components between mainstream and sidestream smoke. III. Middle and higher boiling components; Beitr. Tabakforsch. Int. 12 (1984) 251-258.

39. Brunnemann, K. and D. Hoffmann: The $\mathrm{pH}$ of tobacco smoke; Food Cosmet. Toxicol. 12 (1974) 115- 124.

40. Stedman, R.L., L. Lakritz, and E.D. Strange: Composition studies on tobacco, XXXIII. Changes in smoke composition and filtration by artificial alteration of smoke $\mathrm{pH}$ : Pyridine and nicotine; Beitr. Tabakforsch. 5 (1969) 13-17.

41. Food and Drug Administration: Regulations restricting the sale and distribution of cigarettes and smokeless tobacco products to protect children and adolescents: Proposed rule and analysis regarding FDA's jurisdiction over nicotine-containing cigarettes and tobacco products, notice; Federal Register, 21 CFR Parts 801, 803, 804, and 897, Washington, D.C., August 11, 1995.

42. Joseph, M.J. and E.W. Cochran: Investigation of methods for the analysis of vapor-phase nicotine; $52^{\text {nd }}$ 
Tobacco Science Research Conference, Program Booklet and Abstracts, Vol. 52, No. 27, 1998, p. 28.

43. Joseph, M.J. and E.W. Cochran: The application of a diffusion denuder method for the study of vapor-phase nicotine: The effects of experimental configuration and smoke dilution; $53^{\text {rd }}$ Tobacco Science Research Conference, Program Booklet and Abstracts, Vol. 53, No. 53, 1999, p. 49.

44. Kinser, R., F. Hsu, D. Farthing, L. Johnson, and C. Ellis: Nicotine collection efficiency in the FTC nicotine method; $53^{\text {rd }}$ Tobacco Science Research Conference, Program Booklet and Abstracts, Vol. 53, No. 46, 1999, p. 45.

45. Mariner, D.C. and B.E. Frost: Determination of nicotine evaporation from mainstream smoke using denuder tubes; 1998 CORESTA Congress, October 1998, Brighton, Information Bulletin, Abstract no. ST 18, p. 167.

46. Lewis, D.A., I. Colbeck, and D.C. Mariner: Diffusion denuder method for sampling vapor-phase nicotine in mainstream tobacco smoke; Anal. Chem. 66 (1994) 3525-3527.

47. Lewis, D.A., I. Colbeck, and D.C. Mariner: Dilution of mainstream tobacco smoke and its effects upon the evaporation and diffusion of nicotine; J. Aerosol. Sci. 26 (1995) 841-846.

48. Grob, K and J.A. Völlmin: Analyse der „Semi-Volatiles“ aus Cigarettenrauch mit Hilfe einer Kombination von hochauflösender Gaschromatographie mit Massenspektrometrie; Beitr. Tabakforsch. 5 (1969) 52-57.

49. Mauldin, R.K.: The characterization of cigarette smoke from Cytrel $^{\oplus}$ smoking products and its comparison to smoke from flue-cured tobacco. II. Semi-volatile phase analysis; Beitr. Tabakforsch. 8 (1976) 422-429.

50. Allen, R.E. and D.G. Vickroy: The characterization of cigarette smoke from Cytrel ${ }^{\oplus}$ smoking products and its comparison to smoke from flue-cured tobacco. III. Particulate phase analysis; Beitr. Tabakforsch. 8 (1976) 430-437.

51. Ogden, M.W.: High resolution gas chromatography of tobacco smoke: The contributions of Kurt Grob; J. High Resolution Chrom. \& Chrom. Comm. 11 (1988) 428-440.

52. Borgerding, M.F., R.D. Hicks, J.E. Bodnar, D.M. Riggs, E.J. Nanni, G.W. Fulp, Jr., W.C. Hamlin, Jr., and J.A. Giles: Cigarette smoke composition. Part 1. Limitations of the FTC method when applied to cigarettes that heat instead of burn tobacco; J. Assoc. Anal. Chem. 73 (1990) 605-609.

53. Borgerding, M.F., L.A. Milhous Jr., R.D. Hicks, and J.A. Giles: Cigarette smoke composition. Part 2. Method for determining major components in smoke of cigarettes that heat instead of burn tobacco; J. Assoc. Anal. Chem. 73 (1990) 610-615.

54. Rogers, J.C., L.S. Winkler, and M.F. Borgerding: Chromatographic profiling as a tool in the compari- son and evaluation of complex mixtures; J. Chrom. Sci. 35 (1997) 193-200.

55. Ray, A.K.: Vapor pressure of nicotine; a research report to Brown \& Williamson Tobacco Corporation, 1990, available on the Internet at http://www. brownandwilliamson.aalatg.com/main.htm, Minnesota Bates \#570353407- 570353410.

56. Baker, R.R.: Smoke chemistry; in: Tobacco: production, chemistry and technology, edited by D.L. Davis and M.T. Nielsen, Blackwell Science, Oxford, U.K., 1999, pp. 414-415.

57. Pankow, J.F.: Chemistry of tobacco smoke; $219^{\text {th }}$ National Meeting of the American Chemical Society, San Francisco, CA, Symposium on Chemistry, Pharmacology, and Toxicology of Tobacco, Marijuana, and Related Substances: Pyrolysis Products, Program Book, Abstract TOXI 2 [387376], March 26-27, 2000.

58. Morie, G.P. and M.S. Baggett: Effect of filter ventilation on some physical and chemical properties of cigarette smoke; 1978 CORESTA Congress, Sofia, Bull. Spéc. CORESTA, abstr. S09, Cooperation Center for Scientific Research Relative to Tobacco, Paris, 1978, p. 117

59. Nanni, E.J., M.E. Lovette, R.D. Hicks, K.W. Fowler, and M.F. Borgerding: Separation and quantitation of monovalent anionic and cationic species in mainstream cigarette smoke aerosols by high-performance ion chromatography; J. Chrom. Sci. 28 (1990) 432-436.

60. Sloan, C.H. and G.P. Morie: Determination of unprotonated ammonia in whole cigarette smoke; Beitr. Tabakforsch. 8 (1976) 362-365.

61. Browne, C.L., C.H. Keith, and R.E. Allen: The effect of filter ventilation on the yield and composition of mainstream and sidestream smokes; Beitr. Tabakforsch. Int. 10 (1980) 81-90.

62. Kaneki, K., Y. Masuo, and T. Okada: Determination of particulate matter and carbon oxides in sidestream smoke; Beitr. Tabakforsch. Int. 14 (1989) 155-162.

63. Thome, F.A.: Gas chromatographic determination of the water in cigarette mainstream smoke and total particulate matter; $19^{\text {th }}$ Tobacco Chemists Research Conference, Program Booklet and Abstracts, Vol. 19, No. 33, 1965.

64. Neurath, G., H. Ehmke, and H. Schneemann: Über den Wassergehalt von Haupt- und Nebenstromrauch; Beitr. Tabakforsch. 3 (1966) 351-357.

65. Harris, J.L. and L.E. Hayes: A method for measuring the $\mathrm{pH}$ value of whole smoke; Tob. Sci. 21 (1977) 58-60.

66. Fenner, R.A.: Thermoanalytical characterization of tobacco constituents; Recent. Adv. Tob. Sci. 14 (1988) 82-113.

67. Johnson, W.R., R.W. Hale, S.C. Clough, and P.H. Chen: Chemistry of the conversion of nitrate nitrogen to smoke products; Nature 243 (1973) 223-225. 
68. Hardy, D.R. and M.E. Hobbs: The use of ${ }^{15} \mathrm{~N}$ and of ${ }^{15} \mathrm{~N}$ and ${ }^{16} \mathrm{O}$ in added nitrates for the study of some generated constituents of normal cigarette smoke; Recent Adv. Chem. Chem. Compos. Tob. Tob. Smoke, Symp., Proc. Amer. Chem. Soc. 173 (1977) 489-510.

69. Rickert, W.S.: Partial characterization of 10 'common' brands of American cigarettes; Project report prepared for Massachusetts Department of Public Health, Labstat, Inc., Kitchener, ON, January 30, 1997.

70. Sensabaugh, A.J., Jr. and R.H. Cundiff: A new technique for determining the $\mathrm{pH}$ of whole tobacco smoke; Tob. Sci. 11 (1967) 25-30.

71. Ellis, C.L., R.H. Cox, C.H. Callicut, S.W. Lafoon, K.F. Podraza, and J.I. Seeman: The effect of ingredients, including ammonia compounds, on the FTC nicotine yield and "smoke $\mathrm{pH}$ " of a commercial Marlboro Lights cigarette; $53^{\text {rd }}$ Tobacco Science Research Conference, Program Booklet and Abstracts, Vol. 53, No. 45, 1999, p. 44.

72. Harris, J.L. and L.E. Hayes: A 20-port sidestream smoke collection system; $32^{\text {nd }}$ Tobacco Chemists' Research Conference, Program Booklet and Abstracts, Vol. 32, No. 57, 1978, p. 31.

73. Diana, J.N. and A. Vaught: The research cigarette; The Tobacco and Health Research Institute, Lexington, KY, 1990.

74. R.J. Reynolds Tobacco Co.: Chemical and biological studies on new cigarette prototypes that heat instead of burn tobacco; R.J. Reynolds Tobacco Co., Winston-Salem, NC, 1988, 119-180.

75. Cole, S.K. and P. Martin: Determination of gas-phase sidestream smoke components using Fourier transform infrared spectrometry; Analyst 121 (1996) 495-500.

76. Alford, E.D.: Results of internal/external research on ammoniated reconstituted tobacco. Part I. Purge-and-trap analyses; a research report of Brown \& Williamson Tobacco Corporation, 1985, available on the Internet at http://www.brownand williamson. aalatg.com/main.htm, Minnesota Bates \#570344473- 570344483.

77. Alford, E.D.: Results of internal/external research on ammoniated reconstituted tobacco. Part II. Purge-and-trap analyses of samples prepared with ${ }^{15} \mathrm{~N}$ labeled reagents; a research report of Brown \& Williamson Tobacco Corporation, 1985, available on the Internet at http://www.brownand williamson.aalatg.com/main. htm, Minnesota Bates \#570344487-570344492.

78. Danehy, J.P.: The ubiquitous Maillard reaction; Chemtech. 13 (1983) 412-418.

79. Leffingwell, J.C., H.J. Young, and E. Bernasek: Tobacco flavoring for smoking products; R.J. Reynolds Tobacco Co., Winston-Salem, NC, 1972, 49-52.
80. Shu, C-K. and B.M. Lawrence: Temperature effect on the volatiles formed from the reaction of glucose and ammonium hydroxide: A model system study; Spec. Publ. R. Soc. Chem. 151 (1994) 140-146.

81. Hardt, R. and W. Baltes: Zur Analytik von Zuckercouleuren 1. Mitteilung: Differenzierung der Couleurklassen mittels Curiepunkt-Pyrolyse-Capillargaschromatographie-Massenspektrometrie; Z. Lebensm. Unters. Forsch. 185 (1987) 275-280.

82. Goodman, I.: Glycosyl ureides; Adv. Carbohydr. Chem. 13 (1957) 216-236.

83. Moldoveanu, S.C., C.B. Jenkins, and L.C. Chao: Preparation and identification of 2,5- and 2,6-deoxyfructosazines and their homologues; a research report of Brown \& Williamson Tobacco Corporation, 1987, available on the Internet at http://www.brownandwilliamson.aalatg.com/ main.htm, Minnesota Bates \#570344601- 570344620.

84. Moldoveanu, S.C.: Investigation of some quantitative aspects of sugar-ammonia process; a research report of Brown \& Williamson Tobacco Corporation, 1987, available on the Internet at http://www.brownandwilliamson.aalatg.com/ main.htm, Minnesota Bates \#570348363-570348380.

85. Baker, T.V., J.M. Biltz, F. Carriedo, N.P. Kulshreshtha, J.H. Lauterbach, S.C. Moldoveanu, and W.T. Pannell: Tobacco chemical and cigarette physical analyses on Kentucky reference cigarettes; $52^{\text {nd }}$ Tobacco Science Research Conference, Program Booklet and Abstracts, Vol. 52, No. 47, 1998, p. 36.

86. Burch, S.G., L.P. Gann, K.M. Olsen, P.J. Anderson, F.C. Hiller, and M.L. Erbland: Effect of $\mathrm{pH}$ on nicotine absorption and side effects produced by aerosolized nicotine; J. Aerosol Med. 6 (1993) 45-52.

87. Burch, S.G., M.L. Erbland, L.P. Gann, and F.C. Hiller: Plasma nicotine levels after inhalation of aerosolized nicotine; Amer. Rev. Respir. Dis. 140 (1989) 955-957.

88. Lux, J.E. and R.C. Frecker: Generation of a submicrometre nicotine aerosol for inhalation; Med. Biol. Eng. Comput. 26 (1988) 232-234.

89. Storey, J.M.E. and J.F. Pankow: Gas-particle partitioning of semi-volatile organic compounds to model atmospheric particulate materials. I. Sorption to graphite, sodium chloride, alumina, and silica under low humidity conditions; Atmospheric Environ. 26A (1992) 435-443.

90. Häger, B. and R. Niessner: On the distribution of nicotine between the gas and particle phase and its measurement; Aerosol Sci. Technol. 26 (1973) $163-174$.

91. Nakahara, Y., and A. Ishigami: Inhalation efficiency of free-base cocaine by pyrolysis of 'crack' and cocaine hydrochloride; J. Anal. Toxicol. 15 (1991) 105-109. 
92. Martin, B.R., L.P. Lue, and J.P. Boni: Pyrolysis and volatilization of cocaine; J. Anal. Toxicol. 13 (1989) $158-162$.

93. Houseman, T.H.: Studies on cigarette smoke transfer using radioisotopically labeled tobacco constituents. Part II. The transference of radioisotopically labeled nicotine to cigarette smoke; Beitr. Tabakforsch. 7 (1973) 142-147.

94. Schmeltz, I., A. Wenger, D. Hoffmann, and T.C. Tso: Chemical studies on tobacco smoke. 63. On the fate of nicotine during pyrolysis and in a burning cigarette; J. Agric. Food Chem. 27 (1979) 602-608.

95. Perfetti, T.A.: Structural study of nicotine salts; Beitr. Tabakforsch. Int. 12 (1983) 43-54.

96. Seeman, J.I., J.A. Fournier, J.B. Paine III, and B.E. Waymack: The form of nicotine in tobacco. Thermal transfer of nicotine and nicotine acid salts to nicotine in the gas phase; J. Agric. Food Chem. 47 (1999) 5133-5145.

97. Inciardi, J.A.: Crack cocaine in Miami; in: The epidemiology of cocaine use and abuse; Research monograph 110, edited by S. Schober and C. Schade, US Department of Health and Human Services, Washington, DC, 1991, p. 265.
98. Gori, G.B., N.L. Benowitz, and C.J. Lynch: Mouth versus deep airway absorption of nicotine in cigarette smokers; Pharmacol. Biochem. Behav. 25 (1986) 1181-1184.

99. Benowitz, N.L.: Pharmacokinetics and pharmacodynamics of nicotine; in: The pharmacology of nicotine, edited by M.J. Rand and K. Thurau, ICSU Symposium Series, Vol. 9, IRL Press Limited, McLean, VA, 1998, 3-18.

Address for correspondence:

John H. Lauterbach

Brown \& Williamson Tobacco Corporation

P.O. Box 1056

Macon, GA 31202-1056

Fax: 001-912-464 4018 